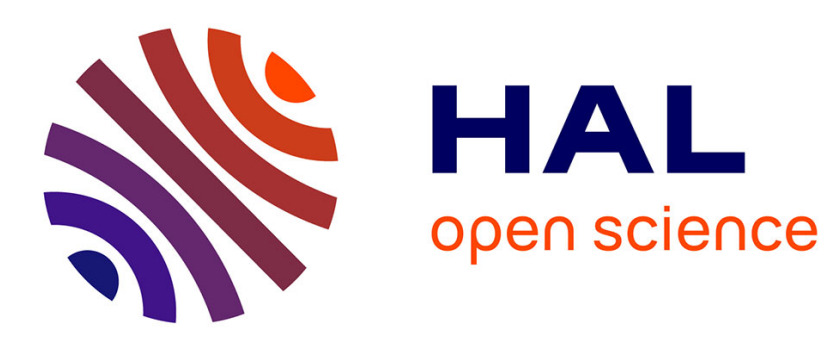

\title{
Analysing regional development and policy: A structural-realist approach
}

Frank Moulaert, Abid Mehmood

\section{To cite this version:}

Frank Moulaert, Abid Mehmood. Analysing regional development and policy: A structural-realist approach. Regional Studies, 2010, 44 (01), pp.103-118. 10.1080/00343400802251478 . hal-00565125

\section{HAL Id: hal-00565125 \\ https://hal.science/hal-00565125}

Submitted on 11 Feb 2011

HAL is a multi-disciplinary open access archive for the deposit and dissemination of scientific research documents, whether they are published or not. The documents may come from teaching and research institutions in France or abroad, or from public or private research centers.
L'archive ouverte pluridisciplinaire HAL, est destinée au dépôt et à la diffusion de documents scientifiques de niveau recherche, publiés ou non, émanant des établissements d'enseignement et de recherche français ou étrangers, des laboratoires publics ou privés. 


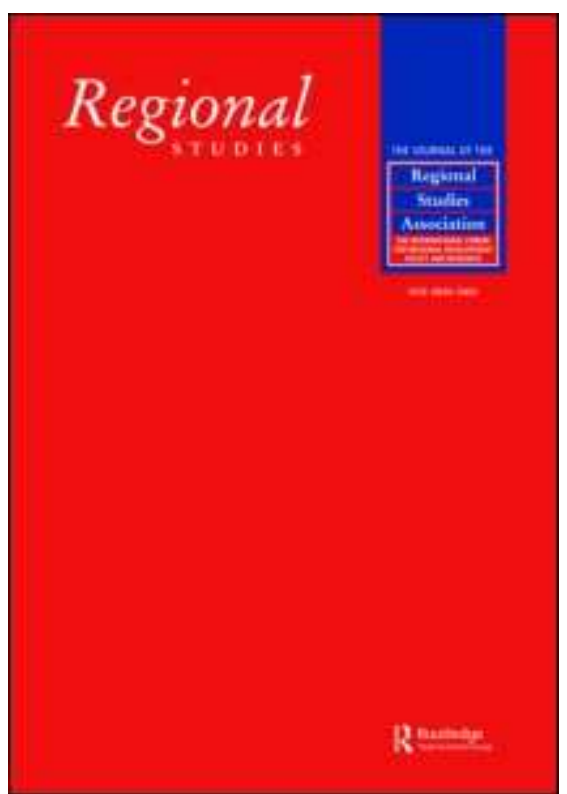

\section{Analysing regional development and policy: A structural- realist approach}

\begin{tabular}{|r|l|}
\hline Journal: & Regional Studies \\
\hline Manuscript ID: & CRES-2007-0026.R1 \\
\hline Manuscript Type: & Critical Surveys \\
\hline JEL codes: & $\begin{array}{l}\text { B0 - General < B - Schools of Economic Thought and Methodology, } \\
\text { R0 - General < R - Urban, Rural, and Regional Economics }\end{array}$ \\
\hline Keywords: & $\begin{array}{l}\text { Territorial Innovation Models, New Regionalism, Regional } \\
\text { development , Path dependency , Social structure, institutions and } \\
\text { culture, Structural realism }\end{array}$ \\
\hline \hline
\end{tabular}

\section{SCHOLARONE" Manuscripts}




\title{
CRITICAL SURVEYS
}

Analysing regional development and policy: A structural-realist approach

\author{
FRANK MOULAERT* ${ }^{*}$ and ABID MEHMOOD ${ }^{+}$ \\ * ASRO, KU Leuven, Kasteelpark Arenberg 51, B-3001 Heverlee, Belgium. \\ Email: Frank.Moulaert@ asro.kuleuven.be \\ ${ }^{+}$GURU, School of Architecture, Planning and Landscape, Newcastle University, \\ Newcastle Upon Tyne, NE1 7RU, UK. Email: Abid.Mehmood@ncl.ac.uk
}

First received: January 2007

Accepted: March 2008

\begin{abstract}
This paper gives an overview of theories and models which can be used to analyse regional development as well as to design policies and strategies for the future of regions and localities. It evaluates the analytical and policy relevance of these models, and as it moves towards analytical synthesis, makes some recommendations for a structural realist approach to spatial development analysis. It offers a methodological framework for contemporary spatial development analysis by combining regulationist, cultural political economy and network theoretical approaches, and taking full cognisance of the structural-institutional, scalar and cultural dimensions of development processes and strategies.
\end{abstract}

Keywords: Territorial Innovation Models - New Regionalism - regional development - path dependency - social structure, institutions and culture - Structural realism. JEL Classifications: $\mathrm{B} 0, \mathrm{R} 0$.

Analyser l'aménagement du territoire: une façon structuralo-réaliste.

Moulaert \& Mehmood

Cet article fournit une vue d'ensemble des théories et des modèles à employer afin d'analyser l'aménagement du territoire aussi bien que de mettre au point des politiques et des stratégies en faveur de l'avenir des régions et des endroits. On évalue l'importance analytique et de politique de ces modèles et, au fur et à mesure que l'on commence à penser une synthèse analytique, on fait quelques recommandations en faveur d'une façon structuralo-réaliste pour analyser le développement géographique. On propose un cadre méthodologique pour analyser le développement géographique contemporain en associant des façons réglementaires, d'économie politique culturelle, et théoriques de réseaux, tout en tenant compte des aspects structuralo-institutionnels, scalaires et culturelles des processus et des stratégies de développement. 
Modèles d'innovation territoriale / Nouveau régionalisme / Aménagement du territoire / Sentier de dépendance / Structure sociale, institutions et culture / Réalisme structurel

Classement JEL: B0; R0

\title{
Analyse der Regionalentwicklung und Politik: ein strukturell-realistischer Ansatz
}

FRANK MOULAERT and ABID MEHMOOD

\begin{abstract}
Dieser Artikel enthält eine Übersicht über die Theorien und Modelle, die sich zur Analyse der regionalen Entwicklung sowie zur Gestaltung von Politiken und Strategien für die Zukunft von Regionen und Orten heranziehen lassen. Wir analysieren die analytische und politische Relevanz dieser Modelle und machen beim Übergang zur analytischen Synthese einige Empfehlungen für einen strukturierten, realistischen Ansatz zur Analyse der räumlichen Entwicklung. Der Artikel bietet einen methodologischen Rahmen zur Analyse der aktuellen räumlichen Entwicklung, indem er die regulationistischen, kulturpolitischwirtschaftlichen und netzwerktheoretischen Ansätze miteinander kombiniert und zugleich die strukturell-institutionellen, skalaren und kulturellen Dimensionen der Entwicklungsprozesse und -strategien vollständig zur Kenntnis nimmt.
\end{abstract}

Keywords:

Territoriale Innovationsmodelle

Neuer Regionalismus

Regionalentwicklung

Pfadabhängigkeit

Sozialstruktur, Institutionen und Kultur

Struktureller Realismus

JEL Classifications: B0, Ro.

Análisis del desarrollo y la política regional: un enfoque realista estructural FRANK MOULAERT and ABID MEHMOOD

Abstract

Este artículo contiene un resumen de las teorías y los modelos que pueden servir para analizar el desarrollo regional y diseñar las políticas y estrategias para el futuro de las regiones y localidades. Evaluamos la relevancia analítica y política de estos modelos y según se va desplazando hacia una síntesis analítica hacemos recomendaciones sobre un 
planteamiento realista y estructural para el análisis del desarrollo espacial. Aquí ofrecemos una estructura metodológica para el análisis contemporáneo del desarrollo espacial al combinar enfoques regulatorios, de la economía política cultural y planteamientos teóricos de redes a la vez que intentamos reconocer completamente las dimensiones institucionales-estructurales, escalares y culturales de los procesos y estrategias del desarrollo.

Keywords:

Modelos de innovación territorial

Nuevo regionalismo

Desarrollo regional

Dependencia de rutas

Estructura social

Instituciones y cultura

Realismo estructural

JEL Classifications: B0, R0.

\section{Introduction}

With the rise (or the 'return'?) of 'Regionalism', the study of regional development and policy has once again become a major focus in social science spatial analysis. To benefit fully of the long tradition of research in this field (say starting with the German Historical School in the $19^{\text {th }}$ century), an equilibrated use of 'old' and 'new' epistemological stances and of ' back to basics' regional analysis are needed - the latter being a plea by Lovering $(2001)^{\mathrm{i}}$. We intend to situate our reading of the literature and search for a new synthesis within a critical-realist approach to society and its spatiality (SAYER, 1992), because such an approach offers a critical and open perspective on the factors and dynamics of social reality, allowing for diversity and complementarity of explanation but still recognising some 'structures with power' within society. The features of the criticalrealist approach, as summarised by Sayer (see endnote $i i$ ), stress that "the view of the 
world is differentiated and stratified consisting not only of events but objects, including structures, which have powers and liabilities capable of generalising events". ii Other features we stress here refer to the independence of reality from our knowledge; the fallibility and theory-based character of knowledge; the production of any other kind of knowledge as a social practice - realism thus clearly requires a 'sociology of knowledge perspective'. Structural realism (SR) then, as a particular focus within realism recognises a relative hierarchy among the objects of social reality and recognises structures in the form of relatively durable social relations as being of a potentially higher causal order. This does not mean that structures are pre-existing to social phenomena; in fact, structures are institutionally mediated and historically as well spatially reproduced through both collective and strategic individual action. Still the conceptual nature of structures, institutions and agency is pre-informed by the theory that has analytically conceived them. This means that within a critical-realist perspective several theories referring to the same or cognate concepts should be confronted and brought into dialogue with each other. A theory privileging the analysis of structures in social reality can also serve as a meta-theoretical framework, which sets in a way the borderlines within which particular objects and their relations can be analysed. Examples of such approaches are well-known in critical geography and spatial development analysis, where the metatheoretical framework adopts the social structures analysed in political economy - and often identifies them as a main feature of its social ontology - but, as in radical political geography, attributes them a deep spatial character (STORPER and WALKER, 1983; MOULAERT, 1987). The critical-realist perspective then requires that, within this framework, theories with different highlights and causal foci will communicate with each 
other and shed light on the different social phenomena and structures that explain regional development and policy. Certainly history plays a significant role in structural realist analysis. Relations between objects, the meaning of cultural change, the conditions and social relations of scientific activity and how it has affected progress or stalemate in society can only historically be laid out.

Having spelled out the epistemological premises of structural-realism, we shall now move to applying these to the review of the regional development literature, starting with the contemporary new regionalism models of territorial innovation, and subsequently work toward a new meta-theoretical synthesis for regional development analysis at the end of the article. Over the last twenty years regional development has been addressed mainly through the bird's eye view of territorial and especially regional innovation models, the spearheads of the so-called 'new regionalism' movement (MOULAERT and MEHMOOD, 2008). These models, discussed in section 2 as Territorial Innovations Models (a generic or family name for Industrial District, Milieu Innovateur, Learning Region, among others; see section 2 for details), were a significant advance on neoclassical regional growth analysis because they enabled the filling of the 'black box' the institutional dynamics of development - traditionally left untouched by neoclassical economics (MOULAERT and SEKIA, 2003). However, territorial innovation models (TIMs) go only half way in solving the methodological problems in regional development and policy analysis. ${ }^{\text {iii }}$ 
This appears from the epistemological reductionism of TIM (a capitalist market economic ontology; collapse of past and future perspectives, empirical and normative stances, institutions and structure, cultural and economic norms) means a backwards step compared to previous regional development theories. Therefore section 3 argues in favour of a return to the 'old' institutionalist tradition of regional development analysis (German Historical School, Gunnar Myrdal, François Perroux, the French school of disequilibrated spatial development, radical geographers of the 1970s, etc.), which by their particular interest in institutions fill the gap between the structure and other objects of social reality. These Schools and authors are more advanced in distinguishing the analytical features of regional development from its design strategy; and by combining these analytical features with recent insights from cultural political economy and relational economic geography; their theories could be made useful relatively easily for contemporary analysis of regional development and policy. The final section is devoted to methodological reflections about the study of regional development. A brief exploration of contemporary attempts to accomplish new syntheses (based on territorial embeddedness, relational complexity, strategic coupling), leads to an explicit choice to connect Cultural Political Economy, Regulationist and 'empowered' network approaches in order to underpin regional development and policy analysis today. Such connection should indeed lead to the definition of a structural-realist meta-theoretical framework within which more issuefocused spatial theories can be brought into use.

\section{Territorial Innovation Models: what are they telling us? ${ }^{\text {iv }}$}


'Territorial Innovation Model' (TIM) are models of regional innovation in which local institutional dynamics play a significant role as catalysts (especially positive) in innovative development strategies. TIMs, as the flagships of New Regionalism, embody an institutional turn in regional development analysis which means a significant step in elaborating a SR approach. Most of these models address the following features of development and innovation as well as the relationships between them: the core of the innovation dynamics, the role of institutions, the view of regional development, culture, the types of relations among agents, and the types of relationships with the environment. Mainly three families of TIM can be identified ${ }^{\mathrm{v}}$. The first contains the Milieu Innovateur and the Industrial District model. The French model Milieu Innovateur, which was the basis for the synthesis produced by GREMI (AYDALOT, 1986), stresses the role of endogenous institutional potential in producing innovative dynamic firms. The same basic idea is found in the Industrial District model, which focuses even more on the role of co-operation and partnership within the innovation process (BECATTINI, 1987). The second TIM family contains models belonging to the tradition of the Systems of Innovation: a translation of institutional co-ordination principles found in sectoral and national innovation systems onto the regional level (EDQUIST, 1997) or, more properly, an evolutionist interpretation of the regional learning economy within the regional space (COOKE, 1996; COOKE and MORGAN, 1998). The third TIM tradition stems from the Californian School of Economic Geography: the New Industrial Spaces (STORPER and SCOTT, 1988; SAXENIAN, 1994). In addition, there is a residual category, encompassing 'spatial clusters of innovation', which is not really another TIM family, as it has little affinity to regional analysis but lies close to Porter's clusters of innovation. 
All these models share a large number of key-concepts that have been used in regional economics or analysis for a long time, or that have been borrowed from other disciplines, especially in social science.

Table 1 summarizes the meaning of territorial innovation and its features in most of these models ${ }^{\mathrm{vi}}$. The learning region model has not been included because it can be considered as an essential synthesis of the features of many of the other TIM models.

\section{INSERT TABLE 1 ABOUT HERE}

Most TIM models stress the instrumentality of institutions in the economic restructuring and enhanced competitiveness of regions and localities. But in none of these models is reference made to improving non-economic dimensions and non-market led sections of regional and local communities, unless such improvements could contribute in some way to the competitiveness of the territory. According to the TIM, quality of life in local and regional communities depends on growth of prosperity and will appear as a positive externality of higher economic growth; no distinction is made between wellbeing and growth, between community culture and business climate.

There is no doubt that TIMs take a significant step forward when compared to orthodox models of spatialised economic 'development' (e.g. neo-classical regional growth models) in that they recognize the explicit role of institutions (including firms) and their learning processes as key factors in economic development. In this way, they fill the 'black box' of the neo-classical model of the firm and its networks which disregards the 
institutional dynamics of innovative agents, and only considers the logic of rational economic agency. TIMs are therefore more socially sophisticated than neoclassical regional growth models, for they perceive institutional dynamics (culture, learning organizations, networks) as improving the market-competitiveness of the local economy. (In orthodox development discourse, one could say that they make 'development' functional to 'growth'; the neo-classical adage turned upside down!). But at the same time TIMs reflect a societal ontology with a restricted view of economic development: innovation and learning will improve the market-economic performance of a region or a locality, and in this way will contribute to the achievement of other developmental goals (economic, social, political, cultural).

In other words: implicitly, TIMs do not consider either the multi-functionality or the allocative diversity of the 'real' economy - an economy that is in reality much broader than the capitalist market economy - or the other existential (non-economic) spheres of local and regional communities, such as the natural environment, the social-cultural (artistic, educational, social services) and the socio-political sphere. Despite their devotion to institutional dynamics, they are sworn to a market-based economic ontology and technological view of development. They blatantly overlook the past and present role of the structural mechanisms of growth and decline, even and uneven inter-regional exchange and development mediated by these institutions and their strategic agencies (HOLLAND, 1976). One could argue that in the TIM view of institutionalisation, the 'lightness of being' of the rationalist behavioural perspective transforms the institutional complexity of the real world and its development paths into self-evident path-breaking 
strategic behaviour - thus rationalising history as if it would be organically engineering the innovative future!

Contrary to a structural-realist perspective the connections between agency, rationality and social relations have also been narrowed down to the latter's functionality for rational economic behaviour pursuing improved competitiveness for the regional or local economy. Another ontological aspect of the market-economist and instrumentalist view of institutional dynamics inherent in TIM is the narrow view of regional economic development policy. In tune with the TIM ontology, economic policy sectors are honed by prioritising technological innovation and rationalist learning procedures, while other sectors are geared towards market-led economic policy. Cultural, educational, transportation, urban development policies, etc. all become more or less subjugated to market competitiveness and lose the raison d'être and policy purpose specific to their own logic in contributing to the cultural, educational, environmental emancipation of human beings and their social groupings (MOULAERT and NUSSBAUMER, 2005).

Finally TIMs suffer from what we could call a 'localist trap'. For a variety of reasons, they regard regional and local development strategies using endogenous resources as the appropriate answer to the uneven and unequal consequences of globalization and power strategies of global players (see for a critical perspective DUNFORD and GRECO, 2006). This position waters down into a naïve misjudgement of the role of the latter and into an unbalanced view of how realistic regional development strategies should take into account both global players and especially their 'focal firms' (COE et al., 2004); at the 
same time this denial of the 'evil of the global', leads to an unrealistic understanding of the power of endogenous resources and how these have been managed. It would, for example, be interesting to apply this perspective to Hassink and Lagendijk's (2001) observations on the 'scant attention to interregional dimension of learning' contrasting with the strong focus on regional learning in regional development analysis. In its most extreme reading the 'localist trap' also means that TIMs are defined in economic and political isolation from the outside world. Old insights (see section 3) that TIMs can only be successful thanks to economies of scale (and not only of scope as TIM do recognise) and high-value added trade networks, and that regions and localities are competitors within a wider economy and polity - with the risk that in absence of appropriate national and supra-national development policies only a limited number among them will succeed - and that macroeconomic dynamics and policy affect the regional development potential seem to have been forgotten (AMIN, 1999). True, contemporary new regionalism analysis is more realistic about this and "places increased weight on extra-local dynamics shaping economic growth within regions" (COE et al., 2004, p. 469); but it remains an enigma why today, in order to bring 'new regionalism' back to this level of geographical complexity, established verities of the 1970s about path-dependency and the meaning of wider spatial scales for development had to be reinvented from scratch.

\footnotetext{
These ontological positions of TIM have inspired at least two major epistemological miscarriages which affect these models' utility for working towards a structural-realist methodology for regional development and policy analysis.
} 
First, TIMs do not manage to disentangle normative from analytical perspectives in regional development research. In realism terms, they neither consider discourse and norm systems as socially produced, nor do they distinguish the specificity of cultural practices. The most significant consequence of this is that intentionality of change in agency' (e.g. innovative strategies, improved organizational learning) is taken as the main driving force of actual regional development. This leads recurrently to a situation in which real-life strategies are analysed as 'imagineered' future behaviour, as if the past and present of regional development can be explained only as the result of rational innovative behaviour within effectively organised learning processes (MOULAERT and SEKIA, 2003), or to a homogenised view of 'best practice' innovation strategies across different types of regions, irrespective of their development path - as rightly criticised by Tödtling and Trippl (2005).

Second, despite TIMs' significant contribution to re-institutionalising the study of territorial development, their analysis of institutional dynamics is framed by the instrumental interpretation of 'territorial institutions for market-led growth' and by what Hess (2004) calls an over territorialized view of embeddedness. This leads for example to either an over deterministic explanation of the role of globalization or a naïve understanding of the width of the manoeuvring space left to endogenous strategies within the global economy and society (DICKEN, 1994).

To overcome these epistemological flaws in the explanation of regional development and policy, we turn in section 3 to 'older' and/or more 'cultured' theories that offer clearer 
explanations of the relationship between past, present and future; agency, structure and institutions; institutions and culture; and development and policy. These theories, therefore, hold potential for developing a structural-realist perspective to this explanation.

More recent attempts to overcome the devotion to local endogeneity and the neglect of articulation between spatial scales have been made by the 'strategic coupling' approach (COE et al., 2004), the revisiting of 'relational economic geography' (YEUNG, 2005), the contextualisation of the territorial embeddedness approach (HESS, 2004) and the path-dependent definition of local development strategies (COX, 2004). These we deal with in the later section 4 , as a spring-board for the presentation of our analytical synthesis.

\section{Old-timers on regional development}

We have seen in section 2 that in contemporary literature on regional development 'new regionalism' and TIMs are playing the first violin. But we noticed that these models suffer from ontological and epistemological reductionism: they use idealised categories of design strategies for future development also as key categories in the analysis of the structural and institutional dynamics of the past, hence short-cutting the causality relations between agency-institutions-structure; and they prototype regional development policy as almost exclusively targeting improved competitiveness. To this end they search for good or best practice combinations of technology and organization, supported by regional and local institutional catalysts. They also tend to overlook the effectiveness of non-economic factors and institutions in regional social and economic 
development (HADJIMICHALIS, 2006). Most TIMs refer to a path dependency of regional development which is usually limited to the continuity of culture patterns and modes of social association between innovative agents and which does not consider the constraining or incapacitating impact of the historical paths followed by the so-called 'abstract' structures of the capitalist economy (division of labour, wage labour relationship, competition between capitals and market structures).

In this section we briefly survey 'old timers' which in their days did not fall victim to institutional instrumentalism and selective a-historicism as we have observed in TIMs. We successively look at Historicism, the schools of disequilibrated growth, and radical economic geography. In the latter part of the section, we also turn to recent contributions in Cultural Political Economy which can be considered as bringing a new dimension to regional development analysis, e.g. by distinguishing different dimensions of cultural practice, important to fulfilling a structural realist perspective.

\subsection{Historicism and territorial development}

The German Historical School has been the basis of the development of $20^{\text {th }}$ century economic growth and development theory. ${ }^{\text {vii }}$ GHS contributions to a better understanding of the Nazionalökonomie and the various analyses of the stages of economic growth have had a major impact on later national and regional development theory and analysis. However, post WW II 'stages of growth' theory can only be indirectly connected to the German Historical School, mainly because the German literature was not well-known to Rostow and others, and also because of the influence of the British classical school on the 
rise of the 'stages of economic growth' analyses which transformed the reading of historical development into a time-series record of economic growth performance indicators (HOSELITZ, 1960). A significant difference between the GHS and the Classical Economists is that the GHS already offered a real theory of economic dynamics (e.g. the idea of cumulative causation) whereas the Classics only provided principles for economic dynamics (such as the role of the changes in the division of labour following Adam Smith) while maintaining the view of an organic tendency towards equilibrium both of the economy and among its agents. viii The GHS contributed to the making of territorial development analysis in the following three ways:

- The recognition of the growing role of the state and the industrialisation

Nussbaumer (2002) demonstrates that significant numbers of ideas found in post Second World War literature on local and regional development were already present to some extent in the writings of the German Historical School. For example, the focus on the social dynamics of development, connected to the building of the Nation State from the different German states; social relations between the Nation-state and economic development; and, the culturally embedded socio-economic organisation of economic activities, have all been active features of discussion in the GHS literature.

- Space as a historical category 
Gustav Schmoller's writings $(1884 ; 1905)$ have applied historical embeddedness to spatial analysis. Using an anthropological perspective, he showed how society appropriated space through the development of institutions that organise it according to the needs of the population. In other words: spatial institutions materialise the social relations that are developed in a community. Therefore, the evolution of needs and the economic system implies a transformation of the institutional configuration of space. The relative importance of institutional levels varies according to their relevance for the development of the (regional, local) community. However institutional evolution is not uniformly harmonious but produces conflicts. Power relations, both within and between institutions, form part of a dialectical movement. The interrelations between economic actors illustrate the political dimension of development; for instance those who try to influence policies by integrating town councils, and political powers that try to orient and promote economic activities. Space, considered from the perspective of its appropriation through (re)institutionalization, is embedded in the movement of history.

- Spatial and territorial approach

The GHS territorial approach to development was mainly developed by Gustav Schmoller. He showed how competition and cooperation within and between institutions are important in creating opportunities for political intervention and for interaction between political action and the transformation of the economic system. This idea, linked to the emphasis on the combination of development factors necessary to generate development and the recognition that social relations within a group or community are 
part of the development process, leads to an analysis of development that links market mechanisms to social interaction.

The contributions of the GHS have had a remarkable influence on the development of later theories of regional endogenous development. Especially, its methodological contributions such as the interactive analysis of causality and its significant impact on methodological collectivism show its affinities with structural realism. And it has also had an impact as one of the pillars of the Regulation Approach (VILLEVAL, 1995) which we deal with in section 3.3.2.

\subsection{Embedded regional development and cumulative disequilibrium}

In the 1960s (or late 1950s) the simultaneous discovery of the difficulties of development in the South and of regional and local problems of development in industrialised countries due to massive transformation of the industrial system (HIRSCHMAN, 1984), highlighted the significance of spatial scales of development and their diversified political and economic dynamics.

However, it would be illusionary to think that a smooth inter-paradigmatic path of scientific progress led from the GHS scholars to the spatial development analysts of the 1960s. In the first half of the $20^{\text {th }}$ century a rupture in the analysis of spatial development [and location] came with the rise of neoclassical location and central place theory. There were many reasons for this paradigmatic discontinuity, of which we cite only the few most important: (i) US scholars' (who until the Interbellum frequently trained at German 
universities) disapproval of German imperial policy - especially under the Nazi regime led to a loss of interest in the GHS that was strongly focused on the role of institutions in general and the State par excellence; (ii) the euphoric spread of positivist scientific methods in social science. Positivist methodology development was invigorated by the rise of formal location analysis, already present at the end of the $19^{\text {th }}$ century, especially in Germany, which began to overrule the GHS approach by the second quarter of the $20^{\text {th }}$ century. We would have to wait till 1980s for a 'mainstream' critical realist answer to the dominant positivist methodology in social science in general, and spatial development analysis in particular.

Gradually a growing separation occurred between pseudo-classical or neo-classical location theory and regional growth theory on the one hand, and institutionalism-rooted regional development theory on the other. The latter includes authors like Myrdal (1957), Hirschman (1958) but also François Perroux (1955; 1983; 1988). Perroux is especially remembered for his analysis of the relationships between economic agglomeration on the one hand (growth poles within geographical space) and externalities (technological, pecuniary) and power relations on the other; his growth pole and regional development analysis adopts a strong institutional perspective and shows how unevenness in economic relations is institutionally confirmed, with only well-established public policy being capable of countering uneven development.

An interesting novel presentation of Myrdal's work on spatial socio-economic development is given by Meardon (2001) who argues: 


\begin{abstract}
"In sum, Myrdal's theory of agglomeration was part of a holistic alternative research program. Its main components were a critique of predominant economic theory, the development and interdisciplinary application of the concept of cumulative causation, and the proposal of public policies intended to reduce international, interregional, and even interracial inequalities - all founded upon explicitly stated value premises.” (p. 49).
\end{abstract}

For our purpose the 'application' of Myrdal's cumulative causation framework to regional and interregional development is of particular interest. He discusses cumulative causation in terms of a tension between backwash and spread effects. He explains how agglomerations often originate as a consequence of either a single or a few economic initiatives (historical accidents) but that their development and dominance over lesser centres is a result of ever increasing internal and external economies in the growth centres. Cultural and political processes play a significant part in this, and the increasing inequality between growth and lesser centres can only be overcome by active and sustained public initiative (MYRDAL, 1957).

The confrontation between these institutionalist regional development analyses and the new regionalism is instructive and shows how the latter has simplified the 'regional world' into an agency space combining institutional and economic engineering - far removed from the real spaces of cumulative causation of growth and development in leading regions and localities, where political power-broking and unequal exchange based trade and investment networks play a significant part. This analysis of Myrdal and others also provides arguments explaining why worldwide maybe a thousand rather than 
a million TIMs will flourish within the real global world and how successful regions will extort resources (human capital, innovative ideas, finance capital) from less successful or poorer regions. ${ }^{\text {ix }}$

\subsection{Political economy of regional development ${ }^{x}$}

The political economy of regional development examines the deployment of the relations of production both within and as reproduced by the 'systems of regions'. Two influential analytical frameworks have been developed quasi simultaneously by Doreen Massey (1984) and Lipietz (1977). Both look at the articulation between the (spatial) hierarchy of the division of labour on the one hand and the reproduction of regional inequality on the other. Later contributors such as Markusen (1983) and Hudson (2001) have broadened the concept of social relations and its role in the analysis of the regionalization process and thus attributed more value to non-reductionist interpretations of regional development; and Sum (2006) has valorised the potential of a more culture-enhanced approach to regional development. These and other authors have stressed the need for better articulation of the different social processes through which space is constantly reproduced - and thus de facto executing Lefèbvre's concept (1974) in which he distinguishes between perceived, conceived and lived space and paves the way for a more counter-hegemonic, lived-diversity based approach to spatial development strategies.

\subsubsection{The spatial division of labour}

In his book 'Le capital et son espace', Alain Lipietz (1977) develops a Marxist theory of regional development. It combines an explanation of the regional inequality problem in 
terms of the condition of the rural economy in France with a spatial division of labour model of manufacturing and service activities across the space-economy. To do so Lipietz analyses 'interregionality' ("les rapports qui s'établissent entre régions inégalement développées au sein d'une zone d'intégration articulée en circuits de branches desservant un marché unique", p. 84) on the basis of the flows or circuits of the branches of production. For this purpose he examines the articulation between 'pre'capitalist relations of production - especially as materialised in traditional agriculture - and the capitalist relations of production as expressed in manufacturing [especially fordist] branches of production. Lipietz analyses explicitly both the development of, and the articulation between, modes of production within the complexity of state - capital relations (i.e. the complexity of national social formations, regional armatures and the over-arching 'imperialist multinational bloc'). He establishes a hierarchical typology of regions: central, intermediary and peripheral. His original empirical basis for this work is the spatial development of industry in relation to agriculture in France; later he completes his analysis using evidence from the regional development of the service sector, which he considers as a further though partial expression of the permanent laws of capital accumulation (concentration, agglomeration of capital, deskilling of direct producers, etc.) and which he links to the deskilling industrialisation of metropolitan regions both internally and at their peripheries (LIPIETZ, 1980: 68).

Doreen Massey's analysis of divisions of labour and the reproduction of uneven spatial development in the UK has strong parallels with Lipietz's in France. Massey (1984: 67): 
"If the social is inextricably spatial and the spatial impossible to divorce from its social construction and content, it follows not only that social processes should be analysed as taking place spatially but also that what have been thought of as spatial patterns can be conceptualised in terms of social processes. [...] The primary social process which the geography of jobs reflects is production. The spatial distribution of employment, therefore, can be interpreted as the outcome of the way in which production is organised over space."

Then Massey develops the argument that the social relations of production are necessarily deployed in space and in a variety of forms, which she calls spatial structures of production. Such spatial structures, although often similar across social spaces, should never be considered as archetypes, deterministically reproduced through the reproductive dynamics of capitalism. Instead the geographical forms of the organisation of production should be examined empirically. In capitalist production systems two distinct types of hierarchies quite often overlap and reinforce each other: (i) the managerial hierarchy comparable to Hymer's (1972) control structure linking headquarters to subsidiaries and branch plants; (ii) the hierarchy of the production process itself with R\&D (often) separated from it; and the production process itself consisting of the production of technically more complex components (engineering) as well as the final assembly of commodities. Massey stresses that, in most cases, a country's national economic geography - perceived as the ensemble of geographical forms of the organisation of the 
economy - "reflects its position in the international political economy, the international division of labour" (p. 82-83).

Both Lipietz and Massey keep underlining that the reproduction of social space is not a one-way causal outcome of the organisation and reproduction of the capitalist production system. Massey: "Spatial structures are established, reinforced, combated and changed through political and economic strategies and battles on the part of managers, workers and political representatives" (p. 85) Political struggle will ultimately determine these forms. However national territories and their spatial organization significantly reflect the unevenness embedded in the corporate hierarchies, be it manufacturing firms (HUDSON, 2001) or service providers and their networks (MARTINELLI and MOULAERT, 1993). But the material outcome of this use of space will ultimately depend on capital-labour relations within the regional system, the strength of the unions and the strength of the class-balance of the State apparatus.

\subsubsection{Cultural and socio-political dimensions of regional development}

Observe that these analyses of regional development, although attaching significant importance to social relations and regulation (especially by the State), still employ an economic interpretation of social relations and their spatial forms. Later work, often influenced by Lefèbvre (1974), such as the regulationist analysis of spatial development (LEBORGNE and LIPIETZ, 1990; MOULAERT, SWYNGEDOUW and WILSON, 1988; MOULAERT and SWYNGEDOUW, 1989; MOULAERT, 1995) and gender and diversity literature (see e.g. BLUNT and WILLS, 2000) broadens the whole idea of social relations in space, and shows how different conceptions of space lead to a better 
understanding of regional development, its potential opportunities and how these feed into the development paths and visions of past and present.

Lefèbvre's generic work on the production of (social) space has had a determining influence on spatial analysis across most disciplines. In his Marxist approach to space, Lefèbvre contrasts perceived, conceived and lived space and addresses the spatial character of each of them by distinguishing spatial practices, representations of space, and representational spaces. Although he stresses the relations of production and their spatial deployment when applying these trialectics to capitalist society, his approach, more than that of Lipietz and Massey, leaves all doors open to look beyond 'abstract' space created by capitalist dynamics, and to include [other than production] social relations, representations of space and representational spaces involved in the reproduction of society and the interaction between hegemonic and counter-hegemonic movements. However, Lefèbvre never breaks the links between production relations and other social relations in society.

In recent years several contributions to regional development analysis have used a broader perspective on social relations, addressing their diversity and their cultural as well as structural dimensions. We cite four contributions in particular:

- Markusen's (1983) work on Regionalism and Regional Development: Markusen explains how territorially defined regions are relevant to political economists when conflicts in social relations of production are perceived as regional conflicts by the actors involved. She calls this perception regionalism, "the espousal of a territorial claim by 
some social group", or in the case of a political movement "the political claim of a territorially identified group of people against one or several mechanisms of the State..." Although 'regionalism' for Markusen is clearly a subjective and experiential term, it can also refer to objective social dynamics that cause territorial differences in social formations. In this way it may refer to the different social relations and institutions which embody or govern relationships within the human community: the household, the State, and cultural institutions.

Because the term region, warns Markusen, "connotes a territorial, not social, entity," its use can lead to a number of epistemological (including conceptual) errors. First, region might be confused with all social relations that are territorially based. As such, a class conflict or a conflict between cultural groups might be wrongly perceived as a conflict between regions (Markusen gives a number of examples). Second, it is probable that the existing territorially defined regions (state, cultural identity, natural habitat, etc.) are only partially relevant to the spatiality of the social relations determining the dynamics of social reality in the region.

Although Markusen explains very well how territorially defined regions can be an issue in political economy, a regional issue itself can only be fully understood if the spatial expression of the social relations - that is, the spatial organization of which the region forms a part - is fully understood also. Markusen's framework recognises the diversity of social relations - beyond strict confinement to (social) relations of production - and thus is highly significant for the analysis of the spatial nature of social and economic development within and across regions and localities. 
- Gender and Diversity. The inclusion of gender and diversity (using a multi-ethnic perspective for example) together with the role of the wage-labour relationship in the analysis of regional development have enriched the understanding of the role of female and migrant labour in regional labour markets (MASSEY, 1984), the uneven reproduction of patriarchal professional hierarchies (MULLINGS, 2005) and the design of alternative emancipation and spatial development strategies (BLUNT and WILLS, 2000).

- Regulation Approach and Local/ Regional Development: The 'territorialization' of the regulationist approach has reinvigorated the debate on the analytical (and strategic) weaknesses of regulation theory and contributed to overcoming them (LEBORGNE and LIPIETZ, 1990; MOULAERT, SWYNGEDOUW and WILSON, 1988; MOULAERT and SWYNGEDOUW, 1989; MOULAERT, 1995; PECK, 1996; PECK and TICKELL, 1992). Reformulating regulationism, after a refreshing territorial bath, is meant to enable this at first National Social Formation oriented analytical framework to address regional development. The revisited regulationist approach includes: (i) an articulated time-space approach to subsequent modes of development and their concrete forms; (ii) a greater focus on the impact of non-economic structural dynamics on regional and local development; (iii) the broadening of the reading of regulatory dynamics from 'pure economic' and 'state agency' to different types of formal and informal regulation; (iv) redefining the role of agency and behavioural codes within the broader definition of institutional dynamics; (v) a reading of social reproduction at the local and regional level which is both extensive and respecting of diversity, and is in tune with recent insights on 
the role of culture, gender and diversity in spatial development strategies, institutionalization and structural transformations; (vi) the recognition of power relations together with social and political struggle as critical analytical categories in regulation theory (MOULAERT, 2000). These improvements to the Regulationist Approach within the territorial regulationist approach resonate with most of the concerns about the onetrack approach of political economy, i.e. overemphasis on the determinist explanatory power of the social relations of production, and how to overcome them, and also several of the concerns of a structural-realist approach to regional development analysis. Not covered in this corrigendum, however, is the role of discourse both in reproducing culture and as a 'real' strategy, which has been a concern of the cultural political economy approach to socio-economic development, but also addresses the cultural concerns of the realist approach.

- Cultural Political Economy and Discourse: Recent work on the relationships between Culture, Discourse, Identity and Hegemony (CDIH) has laid the foundations for an improved integration of two analyses: the analysis of social and cultural embedding of agency and the social construction of institutional change (the 'pure' cultural turn in social science) as well as the more 'structural-materialist' social science analysis stressing the historical specificity and material effectivity of economic categories and practices as applied by e.g. the Regulation Approach or the Strategic-Relational Approach (SUM, 2006; 2005; JESSOP, 2001; JESSOP and SUM, 2006; SUM and JESSOP, 2007). According to Sum (2006) "The CDIH model [within the cultural political economy approach] seeks to develop a more balanced approach that pays due 
attention to the material-discursive nature of social relations, albeit based on a more open conception of social structure (SMART, 1986; FAIRCLOUGH, 1992; JESSOP, 1990; GIBSON-GRAHAM, 1996), as well as to the strategic-discursive moment that is associated with the textual or semiotic aspects of social relations and their emergent properties." (p. 6). Over the last few years Cultural Political Economy (CPE) approaches have enriched regional development analysis by focusing on the role of discourse and identity-building in defining regional and urban policy and interpreting 'histories' of regions and cities. The most promising of these applications are based on the integration of critical discourse analysis into variants of the regulation approach that retain strong residual elements of the Marxist critique of political economy. In this way, CPE takes the cultural turn, with its emphasis on discursive-strategic questions, in the analysis of socioeconomic development without sacrificing the lessons of a materialist-structural analysis of the historically specific socio-economic dynamics of capitalist economies. Following Sum (2005) this integration examines the development of economic imaginaries and associated grand narratives at various interlocked spatial scales; and also explores how these imaginaries and narratives facilitate the emergence and consolidation of not only hegemonic systems (of which they are also an important moment) but also of counterhegemonic movements. Economic imaginaries involve spatio-temporal horizons of action and are institutionalized in specific spatio-temporal matrices and, as such, have major implications for spatial development. In particular, they have a significant impact on how regulation and strategic agency are reproduced at the regional and local level. Moreover, the modes by which grand discourses are reproduced via struggles at the global and national scales are highly relevant in coming to grips with the role of discourse in 
reproduction and accumulation at the local and regional level. Interesting illustrations of this approach are Hajer (1995), Sum (2002) on Hong Kong, Gonzalez (2005 and 2006) for the Basque Country and Bilbao (Northern Spain), Raco (2003) on Scotland, McGuirk (2004) on Sydney, and Moulaert et al. (2007) in relation to urban redevelopment policy in Milan, Antwerp, Vienna and Naples.

One could summarize the discussion in section 3 by arguing that the 'objectivation' of social relations, the broadening of their conceptualisation from economic to social and to cultural dimensions as well as their historical and spatial embedding have made a major contribution to the building of a structural-realist methodology for regional development analysis. These analytical merits will be valorised in the next section, where we will work toward a new synthesis in regional development analysis.

\section{Methodological prospects: toward a structural realist synthesis for regional development analysis}

Over the last fifteen to twenty years the literature on regional development and regional development policy has been dominated by the New Regionalism approach and its Territorial Innovation Models, of which the most popular today is the Learning Region. Although New Regionalism did reintroduce the role of institutional dynamics and path dependency into regional development analysis, unfortunately, its analytical potential soon became constrained by a contemporary reading of the historical and institutional foundations of development, thus reducing path dependency to the reproduction of specific assets and institutions within local and regional communities. At the same time, 
the scalar geography of this approach overplayed the role of the local and regional territory at the expense of interdependencies with other spatial scales. By doing so, the opportunities or constraints stemming from globalization were often miscalculated, and the critical role of supra-regional governance - with still currently an important role for the National state - overlooked. As a consequence, TIMs have become idealised icons of development dreams instead of much needed models addressing the politics and policy of the possible (on the latter, see NOVY and LEUBOLT, 2005; SWYNGEDOUW, 2005). It is therefore of critical importance to move beyond new regionalism, and to develop an alternative perspective to regional development that manages to find a solution to most of the analytical shortcomings mentioned in the earlier sections of this paper. As explained in the introduction, we have opted for a structural realist approach to establish this perspective.

\subsection{Beyond New Regionalism}

Before moving on to our methodological synthesis for regional development analysis, we focus on some recent contributions to overcome some of the flaws of New Regionalism models. We address consecutively the approaches of strategic coupling, of social embeddedness and of relational geography.

Coe et al. (2004) explain how the strategic coupling approach offers a way out of the localist trap overshadowing new regionalism theories and Territorial Innovation Models:

"Drawing upon a global production networks (GPN) perspective and deriving insights from both the new regionalist and GCC (Global Commodity Chain) 
and GVC (Global Value Chain) literatures, our approach focuses on the dynamic 'strategic coupling' of global production networks and regional assets, an interface mediated by a range of institutional activities across different geographical and organizational scales. Our contention is that regional development ultimately will depend on the ability of this coupling to stimulate processes of value creation, enhancement and capture.” (p. 469)

Notwithstanding the fact that the strategic coupling approach offers a major corrigendum to the most localist among the TIMs, it is not really as successful as it pretends in analysing regional development as a set of relational processes. Although we support a process view of regional development, in our opinion processes involve more than relational dynamics as they have been analysed in the relational geography approach.

Two other recent contributions from (economic) geography have scrutinised 'spatial' relationships in development. The 'social embeddedness' approach attempts to bypass the limits of territorial embeddedness - often implicitly assumed in many TIMs. Hess (2004) seeks to do so by illuminating the concept of 'embeddedness'; first by explaining the evolution of embeddedness in Karl Polanyi's work and then moving on to Granovetter's distinction between relational and structural embeddedness, with "the former describing the nature or quality of dyadic relations between actors, while the latter refers to the network structure of relationships between a number of actors" (p. 170-171). Two observations should be made on Hess' synthesis of the 'rescaled' embeddedness approach: it overcomes the local scale bias of embeddedness in a positive way (social embeddedness occurs at related spatial scales); but unfortunately it clings to an 
'interactive' interpretation of social structure - in fact it uses a definition of social structure as 'interactively constructed', not historically and 'societally' reproduced.

A similar observation can be made about Yeung's (2005) critical survey article on relational economic geography which is both illuminating and debate provoking. Yeung inspired by Jessop (2001) - rightly points out that the recent relational turn in economic geography is mainly a thematic one and that an ontological-epistemological relational turn is still to come. He connects the recent popularity of relational thought in economic geography partially to the analytically limited (presumed) structural determinism of Social Relations of Production (and Spatial Division of Labour; see section 3.3.1 above) that leaves little room to analyse mid-range institutionalisation and micro-agency. He compares three recent thematic turns in relational geography: (i) regional and local development as a function of synergised relational assets; (ii) relational embeddedness in networks; (iii) relational scales. (i) coincides largely with the theoretical approach used in the New Regionalism/TIM approach while (ii) matches the 'social embeddedness' line of analysis summarised and revisited by Hess. But (iii) in our opinion offers a misunderstanding of the meaning of the scalar articulation approach. Swyngedouw, Peck, Brenner etc. do not offer a relational geography approach - at least not in the interactive interpretation of relationality which Yeung attributes to these authors - but make a successful attempt to overcome the scale problem of the reproduction of social relations in space (see especially SWYNGEDOUW, 1997). To do so, they improve mainly on the territorialized version of the Regulation Approach which, although it provides the analytical key to the spatial articulation approach, strangely enough is not mentioned in Yeung's article. This observation is not just hair splitting, but points to a significant 
distinction between the meanings of 'relationality' in the different 'relational turns' examined by Yeung. Indeed, for the authors of the scalar articulation approach, relationality refers to social relations in the political economy meaning of the term, and not to interactive dynamics as meant in both the new regionalism or social embeddedness thematic turn. A real 'methodological' relational turn should clarify this distinction, as it should also clarify the distinction in relationality between objects and as social processes. In the Political Economy and the Regulation Approach for example, social relations are not relations between objects but are social processes that are historically and spatially articulated. In consequence, they cannot be changed as a rule through the action of individual actors but through social forces such as (counter) hegemonic movements, institutionalisation processes, cultural upturns,... And they are different ontologically and epistemologically from the type of relationality studied in mainstream network analysis. More careful study is needed therefore of the types of relationality that are relevant to economic geography.

\subsection{Towards a meta-theory for regional development analysis}

To re-equilibrate the framework of regional development analysis, a return is necessary to the 'old' interpretation of institutional dynamics and structural relations. But to lead a comprehensive analysis of regional development these [rediscovered] structures as timeand-place robust institutions and mediated social structures should be combined with an interactionist view of relations between 'development' agents, the specificity of their agency and a cultural perspective on their agency and institutionalization. Keeping in mind the concerns of the SR approach presented in section 1, this synthesis can best be 
achieved by starting from a meta-theoretical framework as suggested by Storper and Walker (1983) and Moulaert (1987). Such a framework is based on a social ontology that includes 'empowered' structural relations in which the capitalist relations of production are dominant, but where 'other' social relations are part and parcel of the social process. This ontology comes quite close to that of the Regulation Approach - sometimes designated as a meta-theory by itself. However, as pointed out in section 3.3.2, the Regulation Approach misses several cultural dimensions and fails to recognise the relative autonomy of social relations in space-and-place. In addition it is poor in dealing with the social and cultural dynamics of agency and its micro-networks. We therefore argue here that to achieve an appropriate framework for regional development analysis, a number of 'open' theories fitting or fittable to the SR approach could be brought together. Open theories, can be considered as theories that denominate a limited number of structures, institutions or typical agencies, but do not provide specific theorisation of the causalities or relations between the objects they host. They can be combined into a metatheoretical synthesis, with a shared social ontology. The synthesis we defend here combines an Empowered Network Perspective (MOULAERT and CABARET, 2006) with a 'Culturalised' Regulation Perspective - an integration of a Regulation Approach with a Cultural Political Economy perspective (JESSOP and SUM, 2006; MOULAERT et al., 2007). Together, these offer a meta-theoretical framework that could host various contributions from old and new institutional and political economy approaches to regional development.

Our support for this meta-theoretical integration is based on our agreement with relational (socio) economic geography that relationality has many dimensions: interaction, 
embeddedness and scalar articulation; at the same time our endeavour is a reaction against the 'networkish' interpretation of relationality inherent in most relational geography applications, which stress the central role of agents as architects of networks and their institutions while overlooking the role of structural relations - as processes - in the reproduction of agency networks and their institutions. To calibrate this reaction, we appeal to a Regulation Approach but one upgraded from a Cultural Political Economy perspective, as argued in section 3 . This allows us to bring structural relations and power into the network metaphor, i.e. to empower network theory. Figure 1 here and the subsequent discussion reflect how a meta-theoretical foundation can be established.

\title{
INSERT FIGURE 1 ABOUT HERE
}

\begin{abstract}
Starting from a detailed reading of network analysis in evolutionary economics and organizational sociology, Moulaert and Cabaret (2006) argue that using the network metaphor as a concept for analysing real-life situations as basically the interaction between agents and the resulting outcomes, is a logical intellectual ambition:
\end{abstract}

\begin{abstract}
"Human life, organizations and agencies are based on interactions between human beings that are to a large extent networked amongst themselves. Agents (individuals, organizations) develop and share cultures, modes of communication, principles of (network) action and ways of building institutions. These institutions will of course not just be the outcome of voluntary institutional engineering within the networks, but will also depend on the interaction between the network
\end{abstract}


dynamics, the network environment and the development paths of the society and communities to which the network belongs. Thus network theory is useful in modelling strategies and policy actions in regional and local development." (p. 54).

Better than 'structural' social theories, the network metaphor, by looking at cognitive processes, the role of network culture and the production of discourse, offers a natural link to cultural political economy. However, most current network theories defend reductionist rational approaches to human behaviour (for a critique, see HADJIMICHALIS and HUDSON, 2006), stress the role of procedures in information gathering, exchange and institution building but deal very poorly with social structures, power and power-relations. To overcome this weakness, Regulation Theory can step in.

\begin{abstract}
Although Regulation Theory, like Marxism, primarily looks at economic (strategic) behaviour, its theorising of social and political structure as social relations focused on power relations and institution building as a social process, is relevant to 'empowering networks' within society. Similarly, property relations, labour-capital relations, finance capital, the State as an extended logic of capital, etc. play a direct role in most networks embedded in the socio-economic world. In network terminology, this means that stakeholders hold significantly unequal stakes, the decision-making space is limited or uneven, and, in extreme cases, the outcome of negotiation processes is known beforehand, because the structural-institutional impact of the logic of capital and politics is so influential. By using the embeddedness approach of Polanyi and Granovetter, we
\end{abstract}


could not only embed the network analysis of strategic behaviour and policy making by leading regional and local agents within the Regulationist Approach of social relations, but also use that approach to study the reproduction of the economic, political, social and cultural structures of the region and its localities (MOULAERT and SWYNGEDOUW, 1989).

These structures - together with the networks embodying their micro-dynamics - then become 'encultured', under the Cultural Political Economy's revisiting of social analysis by looking at the role of culture, identity and discourse and how they affect social forces and strategic agency. As indicated in section 3 the work of Sum $(2005,2006)$ in particular has been bridge-building in this respect. Inspired by Jessop (1990) and AngloFoucauldian theorists such as Rose and Miller (1992) and Dean (1999), Ngai-Ling Sum has designed a heuristic device that links the macro and micro processes - especially stressing the role of discourse - of hegemony and counter-hegemony making. In six interrelated moments that highlight the discursive dimensions of social relations and individual and collective agency, she provides the concepts necessary to analyse the relationship between 'real' and 'cultural' articulation via the examination of struggles involved in the material-discursive practices of everyday life. As shown in cited casestudies (section 3) this adds real value to the understanding of culture and discourse in regional and local development and policy.

As explained before we label the integration tripod of network theory, regulation approach and cultural political economy as a 'meta theoretical framework' because it 
provides a social ontology and epistemology for spatial development analysis, but does not expand the specific theories that shed light on the various dimensions and questions of regional and local development. To this end, we should return to the survey of theories in sections 2 and 3 which offer specific intelligence on each of these dimensions: e.g. Myrdal on economic and political factors and mechanisms of centre-periphery relations, Hirschman on the significance of political processes in regional development, Lipietz on the links between the reproduction of economic structure and the State apparatus, Markusen on the role of social and political movements in the regionalization process; and many others. Looking at these theories within this newly defined triangular field of 'social relations - networks of agents - cultural dynamics' may offer a wind of change yet one redolent of the prickling dust of historical manuscripts that are badly needed today but have rested for too long on library shelves - in addressing regional development and policy. 


\title{
5. References
}

\author{
AMIN A. (1999) An institutionalist perspective on Regional Economic Development, \\ International Journal of Urban and Regional Research, 23(2), 365-378.
}

\begin{abstract}
AYDALOT Ph. (1986) Milieux innovateurs en Europe. (Innovative 'Milieux' in Europe). GREMI, Paris.

BECATTINI G. (1987) Mercato e forze locali: il distretto industriale.Il Mulino, Bologna.
\end{abstract}

BLUNT, A. and WILLS, J. (2000) Dissident Geographies: An introduction to radical ideas and practice, Pearson Education, Harlow.

\author{
COE, N.M., HESS, M., YEUNG, H.W.C., DICKEN, P., and HENDERSON, J. (2004) \\ 'Globalizing' regional development: a global production networks perspective, \\ Transactions of the Institute of British Geographers 29(4), 468-484
}

\begin{abstract}
COOKE, Ph. (1996) Reinventing the region: firms, clusters and networks in economic development, in DANIELS, P. and LEVER, W. (Eds) The global economy in transition. Longman, Harlow.
\end{abstract}


COOKE, Ph. and Morgan, K. (1998) The Associative Region, Oxford University Press, Oxford.

COX, K.R. (2004) Globalization and the politics of local and regional development: the question of convergence, Transactions of the Institute of British Geographers 29(2), 179194

DEAN, M. (1999) Governmentality: Power and Rule in Modern Society, Sage, London.

DICKEN, P. (1994) The Roepke Lecture in Economic Geography. Global-Local

Tensions: Firms and States in the Global Space-Economy. Economic Geography 70(2), 101-128.

DUNFORD, M. (1988) Capital, the State and Regional Development, London, Pion

DUNFORD, M and GRECO, L. (2006) After the Three Italies, Blackwell, Oxford.

EDQUIST, Ch. (Ed) (1997), Systems of Innovation: Technologies, Institutions and Organizations. Pinter, London

FAIRCLOUGH, N. (1992) Discourse and Social Change. Polity, Cambridge. 
FUJITA, M. KRUGMAN, P. and VENABLES, A.J. (1999) Spatial Economy. Cities, regions, and international trade. MIT Press, Cambridge MA.

GIBSON-GRAHAM, J.K. (1996) The End of Capitalism. Blackwell, Oxford.

GONZALEZ, S. (2005) The politics of the economic crisis in the Basque Country and Spain during the 1980s. Space and Polity 2005, 9(2), 93-112.

GONZALEZ, S (2006) Scalar narratives in Bilbao: A cultural politics of scales approach to the study of urban policy. International Journal of Urban and Regional Research. 30(4), 836-857.

HADJIMICHALIS, C. (2006) Non-economic factors in economic geography and in 'new regionalism': A sympathetic critique. International Journal of Urban and Regional Research, 30(3), 690-704.

HADJIMICHALIS, C. and HUDSON, R. (2006) Networks, Regional Development and Democratic Control. International Journal of Urban and Regional Research, 30(4), $858-872$.

HAJER, M. (1995) The politics of environmental discourse. Ecological modernization and the policy process, Oxford University Press, Oxford. 
HARVEY, D. (1982) The Limits to Capital, The University of Chicago Press, Chicago.

HASSINK, R. and LAGENDIJK, A. (2001) The dilemmas of interregional institutional learning, Environment and Planning C: Government and Policy, 19(1), 65-84.

HESS, M. (2004) 'Spatial' relationships? Towards a reconceptualization of embeddedness, Progress in Human Geography, 28(2), 165-186

HIRSCHMAN, A. O. (1958) The strategy for economic development, Yale University Press, New Haven CT

HIRSCHMAN, A.O. (1984) The On and Off Connection Between Political and Economic Progress, The American Economic Review, 84(2), 343-348.

HOLLAND S. (1976) Capital versus the Regions, The MacMillan Press, London.

HOSELITZ, B. F. (1960) Theories of Economic Growth, Free Press, New York.

HUDSON, R. (2001) Producing Places. Guilford, New York.

HYMER, S. (1972) The multinational corporation and the law of uneven development, in BHAGWATI, J. (Ed), Economics and the World Order, The Macmillan Press, London. 
JESSOP, B. (1990) Regulation Theories in Retrospect and Prospect, Economy and Society, 19(2), 153-216.

JESSOP, B. (2001) Institutional re(turns) and the strategic relational approach, Environment and Planning A, 33(7), 1213-1235.

JESSOP, B. and SUM, N-L. (2006) Beyond the regulation approach: putting capitalist economies in their place, Edward Elgar, Cheltenham

KEATING, M. (1998) The New Regionalism in Western Europe: territorial restructuring and political change. Edward Elgar, Cheltenham.

LEBORGNE, D. and LIPIETZ, A (1990) Fallacies and Open Issues of Post-Fordism, Couverture Orange , no. 9009, CEPREMAP, Paris

LEFÈBVRE, H. (1974) [2004] The Production of Space. Blackwell, Oxford.

LIPIETZ, A. (1977) Le Capital et son Espace. Maspero, Paris.

LIPIETZ, A. (1980) Le teriaire, arborescence de l'accumulation capitaliste: prolifération et polarisation. Critiques de l'Economie Politique, July-September, 17-69. 
LÖSCH, A. (1938) The nature of economic regions, Southern Economic Journal, 5(1), 71-78

LOVERING, J. (2001) The Coming Regional Crisis (And How To Avoid It), Regional Studies, 35(4), 349-54.

MACKINNON, D., CUMBERS, A., and CHAPMAN, K. (2002) Learning, innovation and regional development: a critical appraisal of recent debates, Progress in Human Geography 26(3), 293-311

MARTINELLI, F. and MOULAERT, F. (1993) The Location of Advanced Producer Services Firms: Theory and Illustrations. Geographische Zeitschrift, 81(1-2), 1-17.

MARKUSEN A., (1983), Regions and Regionalism, in MOULAERT, F. and WILLSON P. (Eds) Regional Analysis and the New International Division of Labor, Kluwer Nijhoff Publishing, Boston.

MASSEY, D. (1984) Spatial Divisions of Labour. Social structures and the geography of production, Macmillan, London.

M ${ }^{C}$ GUIRK, P. (2004) State, strategy and scale in the competitive city: a neo-gramscian analysis of the governance of 'global Sydney'. Environment and Planning A, 36(6), 1019-1043. 
MEARDON, S. J. (2001) Modelling Agglomeration and Dispersion in City and Country:

Gunnar Myrdal, François Perroux, and the New Economic Geography', American

Journal of Economics and Sociology, 60(1), 25-57

MOULAERT, F. (1987) An Institutional Revisit of the Storper-Walker Theory of Labor. International Journal of Urban and Regional Research, 11(3), 309-330.

MOULAERT, F. (1996) Rediscovering spatial inequality in Europe. Building blocks for an appropriate "regulationist" framework. Society and Space, 14(2), 155-179

MOULAERT, F. and CABARET, K. (2006) Planning, networks and power relations: Is democratic planning under capitalism possible? Planning Theory, 5(1), 51-70.

MOULAERT, F., MARTINELLI, F., GONZALEZ, S., and SWYNGEDOUW, E. (2007) Social Innovation and Governance in European Cities: Urban development between path dependency and radical innovation, European Urban and Regional Studies, 14(3), 195209.

MOULAERT, F. and MEHMOOD, A. (2008) Analysing regional development: From territorial innovation to path dependent geography, in Davis, J. and Dolfsma, W. (Eds.) The Elgar Companion to Social Economics, Edward Elgar, Cheltenham 
MOULAERT, F. and NUSSBAUMER, J. (2005) The Social Region: Beyond the territorial dynamics of the learning economy, Journal of European Urban and Regional Studies, 12(1), 45-64.

MOULAERT, F. and SEKIA, F. (2003) Territorial Innovation Models: a Critical Survey, Regional Studies, 37(3), 289-302.

MOULAERT, F., SEKIA, F., and BOYABÉ, J.B. (1999) Innovative region, social region? An alternative view of regional innovation, IFRESI Discussion Paper, Lille

MOULAERT, F., SWYNGEDOUW, E. and WILSON, P. (1988) The Geography of Fordist and Post-Fordist Accumulation and Regulation, Papers of the Regional Science Association, 64, 11-23.

MOULAERT, F. and SWYNGEDOUW, E. (1989) 'Survey 15: A regulation approach to the geography of flexible production systems', Environment and Planning D: Society and Space, 7(3), 327-345.

MYRDAL G. (1957) Economic Theory and Underdeveloped Regions, Duckworth, London.

MULLINGS, B. (2005) Women Rule? Globalization and the feminization of managerial and professional workspaces in the Caribbean, Gender, Place and Culture, 12(1), 1-27 
NOVY, A. and B. LEUBOLT (2005) Participatory Budgeting in Porto Alegre: Social Innovation and the Dialectical Relationship of State and Civil Society. Urban Studies, 42(11), 2023-2036.

NUSSBAUMER, J. (2002) 'Le rôle de la culture et des institutions dans les débats sur le développement local: la contribution de l'Ecole Historique Allemande' [The role of culture and institutions in the debates on local development: the contribution of the German Historical School], unpublished PhD thesis, Lille: University of Lille I, Faculty of Social Science.

PECK, J (1996) Work Place. The Social Regulation of Labor Markets, The Guilford Press, New York/London.

PECK, J. and TICKELL, A. (1992) Local modes of social regulation? Regulation theory, Thatcherism and uneven development. Geoforum, 23(3), 347-364.

PERROUX, F. (1955) Note sur la notion de "pôle de croissance", Economie Appliquée 8. Republished and translated in McKEE, D. L., DEAN, R.D. and LEAHY, W.H. (Eds) (1970) Regional Economics, pp. 93-103, The Free Press, New York.

PERROUX, F. (1983) A New Concept of Development: Basic Tenets, Croom Helm, London 
PERROUX, F., (1988) 'The Pole of Development's New Place in a General Theory of Economic Activity', in HIGGINS, B. and SAVOIE, D.J. (Eds) Regional Economic Development: Essays in Honour of François Perroux, pp. 48-76, Unwin Hyman, Boston.

RACO, M. (2003) Governmentality, Subject-Building and the Discourses and Practices of Development in the UK, Transactions of the Institute of British Geographers, 28(1), 75-95.

ROSE, N. and MILLER, P. (1992) Political Power Beyond the State: Problematics of Government, British Journal of Sociology, 43(2), 173-205.

SAYER, A. (1992) Method in Social Science: A Realist Approach, Routledge, London.

SAXENIAN, A. (1994) Regional Advantage. Culture and Competition in Silicon Valley and Route 128. Harvard University Press, Cambridge.

SCHMOLLER, F.G. (1884) Das Merkantilsystem in seiner historischen Bedeutung:

Städtische, territoriale und staatliche Wirtschafts-politik, Jahrbuch für Gesetzgebung, Verwaltung und Volkswirtschaft im Deutschen Reich, VIII 15-61

SCHMOLLER, F.G. (1905) Principes d'Economie Politique, V.Giard et E. Brière, Paris. 
SMART, B. (1986) The Politics of Truth and the Problem of Hegemony, in HOY, D.C. (Ed.) Foucault: A Critical Reader, pp. 157-73, Basil Blackwell, Oxford.

STORPER, M. and SCOTT, A.J. (1988) The Geographical Foundations and Social Regulation of Flexible Production Complexes, in WOLCH, J. and DEAR, M. (Eds) The Power of Geography. pp. 21-40, Allen and Unwin, London.

STORPER, M. and WALKER, R. (1983) The theory of labor and the theory of location. International Journal of Urban and Regional Research 7(1), 1-44.

SUM, N-L. (2002) Globalization and Hong Kong as an Entrepreurial City Strategies: Contested Visions and the Remaking of City Governance in (Post-) Crisis Hong Kong, in LOGAN, J. (Ed.) The New Chinese City: Globalization and Market Reform, pp. 74-91, Blackwell, Oxford.

SUM, N-L. (2005) From the Regulationist Approach to Cultural Political Economy. DEMOLOGOS working paper, [on website: http://demologos.ncl.ac.uk/wp/wp1/disc.php December 2005].

SUM, N-L. (2006) Culture, Discourse, Ideology, and Hegemony, DEMOLOGOS working paper, [on website: http://demologos.ncl.ac.uk/wp/wp2/disc.php August 2006] 
SUM, N-L. and Jessop, B. (2007) Towards a Cultural Political Economy, Edward Elgar, Cheltenham.

SWYNGEDOUW, E. (1997) La Reconstruction de la Choreographie Espace / Temps de la Monnaie Mondiale. Espaces et Sociétés, 88-89, 53-90

SWYNGEDOUW, E. (2005) Governance Innovation and the Citizen: The Janus Face of Governance-beyond-the-State. Urban Studies, 42(11), 1991-2006.

TÖDTLING, F. and TRIPPL, M. (2005) One size fits all? Towards a differentiated regional innovation policy approach. Research Policy, 34, 1203-1219.

VILLEVAL, M.C. (1995) Une théorie économique des institutions? in BOYER, R. and SAILLARD, Y. (Eds) L'Ecole de la Régulation. L'Etat des Savoirs. pp. 479-489, Presses Universitaires de France, Paris.

WILLIAMS, A.M., BALAZ, V., and WALLACE, C. (2004) International Labour Mobility and Uneven Regional Development in Europe: Human Capital, Knowledge and Entrepreneurship, European Urban and Regional Studies, 11(1), 27-46

YEUNG, H. Wai-Chung (2005) Rethinking Relational Economic Geography, Transactions of the Institute British Geographers, 30(1), 37-51 


\section{Table 1 Views of innovation in territorial innovation models}

\begin{tabular}{|c|c|c|c|c|}
\hline $\begin{array}{r}\text { Model } \\
\text { Features of innovation }\end{array}$ & $\begin{array}{l}\text { Milieu innovateur } \\
\text { (Innovative milieu) } \\
\text { (MI) }\end{array}$ & Industrial District (ID) & $\begin{array}{l}\text { Regional Innovation } \\
\text { Systems (RIS) }\end{array}$ & New Industrial Spaces \\
\hline $\begin{array}{l}\text { Core of innovation } \\
\text { dynamics }\end{array}$ & $\begin{array}{l}\text { Capacity of a firm to } \\
\text { innovate through the } \\
\text { relationships with other } \\
\text { agents of the same } \\
\text { milieu }\end{array}$ & $\begin{array}{l}\text { Capacity of actors to } \\
\text { implement innovation } \\
\text { in a system of common } \\
\text { values }\end{array}$ & $\begin{array}{l}\text { Innovation as an } \\
\text { interactive, cumulative } \\
\text { and specific process of } \\
\text { research and } \\
\text { development (path } \\
\text { dependency). }\end{array}$ & $\begin{array}{l}\text { A result of } \mathrm{R} \& \mathrm{D} \text { and } \\
\text { its implementation; } \\
\text { application of new } \\
\text { production methods } \\
\text { (JIT, etc.) }\end{array}$ \\
\hline Role of institutions & $\begin{array}{l}\text { Very important role of } \\
\text { institutions in the } \\
\text { research process } \\
\text { (university, firms, } \\
\text { public agencies, etc.) }\end{array}$ & $\begin{array}{l}\text { Institutions are } \\
\text { "agents" and enabling } \\
\text { social regulation, } \\
\text { fostering innovation } \\
\text { and development }\end{array}$ & $\begin{array}{l}\text { As in the NIS, the } \\
\text { definitions vary } \\
\text { according to authors. } \\
\text { But they all agree that } \\
\text { the institutions lead to } \\
\text { a regulation of } \\
\text { behaviour, both inside } \\
\text { and outside } \\
\text { organisations }\end{array}$ & $\begin{array}{l}\text { Social regulation for } \\
\text { the co-ordination of } \\
\text { inter-firm transactions } \\
\text { and the dynamics of } \\
\text { entrepreneurial activity }\end{array}$ \\
\hline Regional development & $\begin{array}{l}\text { Territorial view based } \\
\text { on "milieux } \\
\text { innovateurs" and on } \\
\text { agent's capacity of } \\
\text { innovating in a co- } \\
\text { operative atmosphere }\end{array}$ & $\begin{array}{l}\text { Territorial view based } \\
\text { on spatial solidarity } \\
\text { and flexibility of } \\
\text { districts. This } \\
\text { flexibility is an } \\
\text { element of this } \\
\text { innovation }\end{array}$ & $\begin{array}{l}\text { View of the region as a } \\
\text { system of "learning by } \\
\text { interacting/ and by } \\
\text { steering regulation", }\end{array}$ & $\begin{array}{l}\text { Interaction between } \\
\text { social regulation and } \\
\text { agglomerated } \\
\text { production systems }\end{array}$ \\
\hline Culture & $\begin{array}{l}\text { Culture of trust and } \\
\text { reciprocity links }\end{array}$ & $\begin{array}{l}\text { Sharing values among } \\
\text { ID agents - Trust and } \\
\text { reciprocity }\end{array}$ & $\begin{array}{l}\text { The source of "learning } \\
\text { by interacting" }\end{array}$ & $\begin{array}{l}\text { Culture of networking } \\
\text { and social interaction }\end{array}$ \\
\hline $\begin{array}{l}\text { Types of relations } \\
\text { among agents }\end{array}$ & $\begin{array}{l}\text { The role of the support } \\
\text { space: strategic } \\
\text { relations between the } \\
\text { firm, its partners, } \\
\text { suppliers and clients }\end{array}$ & $\begin{array}{l}\text { The network is a social } \\
\text { regulation mode and a } \\
\text { source of discipline. It } \\
\text { enables a coexistence } \\
\text { of both co-operation } \\
\text { and competition }\end{array}$ & $\begin{array}{l}\text { The network is an } \\
\text { organisational mode of } \\
\text { "interactive learning" }\end{array}$ & Inter-firm transactions \\
\hline $\begin{array}{l}\text { Types of relations } \\
\text { with the environment }\end{array}$ & $\begin{array}{l}\text { Capacity of agents in } \\
\text { modifying their } \\
\text { behaviour according to } \\
\text { the changes in their } \\
\text { environment. Very } \\
\text { 'rich' relations: third } \\
\text { dimension of support } \\
\text { space }\end{array}$ & $\begin{array}{l}\text { The relationships with } \\
\text { the environment } \\
\text { impose some } \\
\text { constraints and new } \\
\text { ideas. Must be able to } \\
\text { react to changes in the } \\
\text { environment. 'Rich' } \\
\text { relations. Limited } \\
\text { spatial view of } \\
\text { environment }\end{array}$ & $\begin{array}{l}\text { Balance between inside } \\
\text { specific relations and } \\
\text { environment } \\
\text { constraints. 'Rich' } \\
\text { relations }\end{array}$ & $\begin{array}{l}\text { The dynamics of } \\
\text { community formation } \\
\text { and social reproduction }\end{array}$ \\
\hline
\end{tabular}




\section{Figure 1 A meta-theoretical synthesis for regional development analysis: Regulation, Network and CPE approaches}

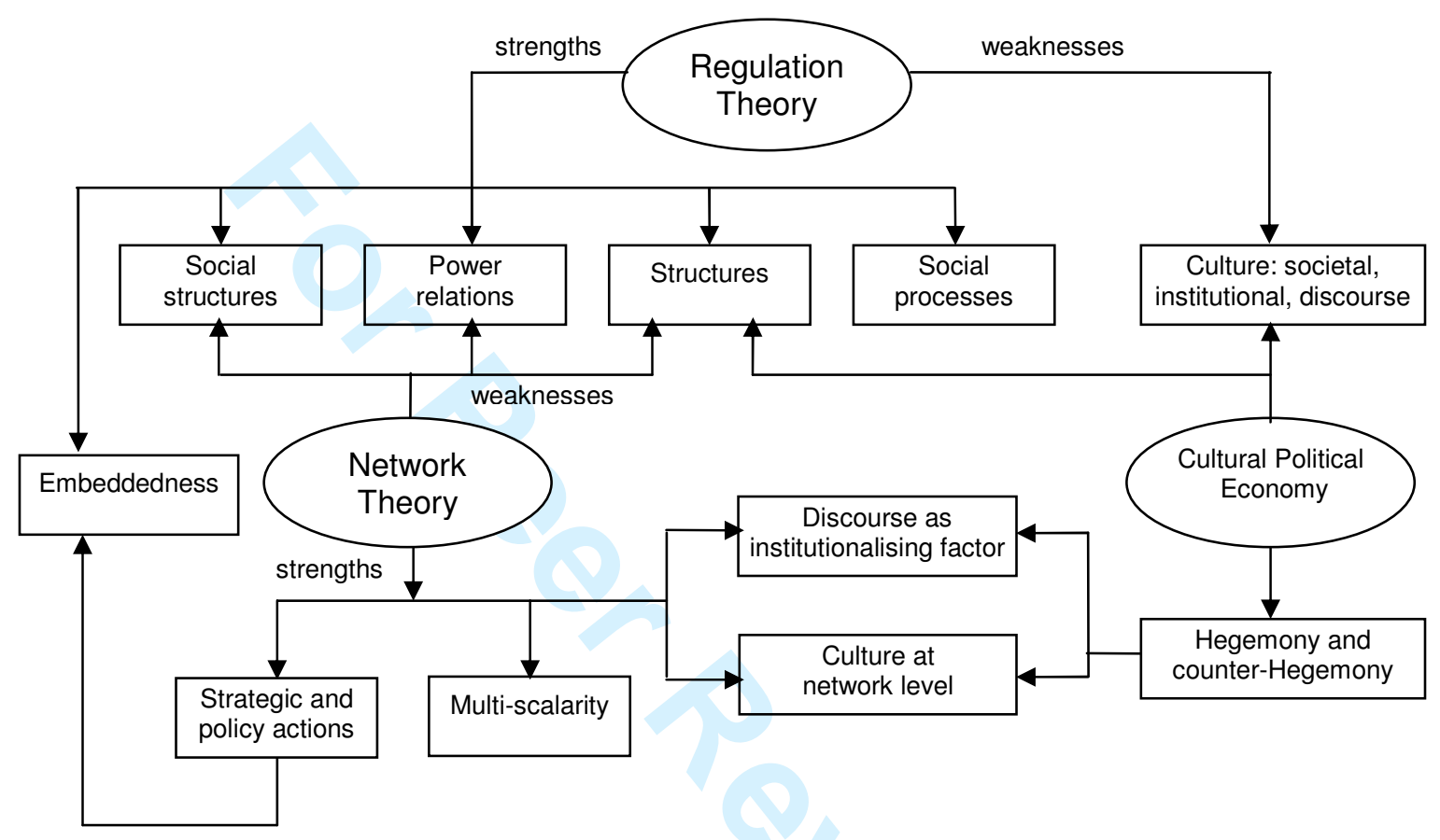




\section{Endnotes}

\footnotetext{
${ }^{\mathrm{i}}$ This paper does deal with regional development, not regional growth theories. Although there exist affinities between both analytical traditions, we have no space to deal with both and we prefer to address the more 'quality features' oriented development theories. As a consequence we will for example not present the debate on/between New Economic Geography and regional endogenous growth models (see e.g. FUJITA, KRUGMAN and VENABLES, 1999).

${ }^{\text {ii }}$ Andrew Sayer has summarised the realist scientific-philosophical approach as having the following features: (a) the world exists independently of our knowledge of it; (b) our knowledge of the world is preinformed but also imperfect; (c) "Knowledge develops neither wholly continuously, as the steady accumulation of facts within a stable conceptual framework, nor wholly discontinuously, through simultaneous and universal changes in concepts." (p. 5) (d) objects (natural or social) have particular causal powers or ways of acting and particular susceptibilities; (e) "The world is differentiated and stratified, consisting not only of events, but objects, including structures, which have powers and liabilities capable of generating events." [...] (f) "Social phenomena such as actions, texts and institutions are concept dependent" (p. 6) [...] (g) "Science or the production of any other kind of knowledge is a social practice. For better or worse (not just worse) the conditions and social relations of the production of knowledge influence its content. Knowledge is also largely - though not exclusively - linguistic, and the nature of language and the way we communicate are not incidental to what is known as communicated. Awareness of these relationships is vital in evaluating knowledge."; (h) "Social science must be critical of its object"” $[\ldots]($ p. 6)

iii Contemporary debates on New Regionalism take different directions, especially following criticisms of the neglect of articulation among spatial scales and their consequences for economic policy. We have reserved the term 'New Regionalism' for the original spatially disarticulated models, preferring to refer to the spatially articulated models as 'Beyond New Regionalism'. - see section 4.1. Neither do we address the political science literature on New Regionalism (see e.g. KEATING, 1998). Although we believe that Markusen's Regionalism concept (section 3.3.2) could play a significant role there.
} 
${ }^{\text {iv }}$ This section has been reproduced and extended from Moulaert and Nussbaumer (2005). Copyright granted by SAGE Publications.

${ }^{\mathrm{v}}$ For details see Moulaert, Sekia and Boyabé (1999).

${ }^{\mathrm{vi}}$ For more details see Moulaert, Sekia and Boyabé, op. Cit. See also MacKinnon, Cumbers and Chapman (2002) who among other critical observations point out how the learning region model underemphasises the articulation among spatial scales in learning dynamics.

vii The GHS also played a significant role in the genesis of location theory; this is not developed here. See Nussbaumer (2002).

viii We should also keep in mind that the theory of stages of economic growth also had an influence on Lösch's theory of system of regions (LÖSCH 1938).

${ }^{\text {ix }}$ See also Williams et al. (2004) on the relationship between migration flows and uneven development in contemporary Europe.

${ }^{\mathrm{x}}$ We selected these two authors because their focus is regional compared to other authors from the1970s working in radical political geography and their analysis fits best the trajectory leading to the structuralrealist synthesis in regional development analysis, which we pursue. If we had to further extend this methodological exercise we would certainly make made use of Dunford (1988) and Harvey (1982) 


\title{
CRITICAL SURVEYS
}

Analysing regional development and policy: A structural-realist approach

\author{
FRANK MOULAERT* ${ }^{*}$ and ABID MEHMOOD ${ }^{+}$ \\ * ASRO, KU Leuven, Kasteelpark Arenberg 51, B-3001 Heverlee, Belgium. \\ Email: Frank.Moulaert@ asro.kuleuven.be \\ + GURU, School of Architecture, Planning and Landscape, Newcastle University, \\ Newcastle Upon Tyne, NE1 7RU, UK. Email: Abid.Mehmood@ncl.ac.uk
}

First received: January 2007

Accepted: March 2008

\begin{abstract}
This paper gives an overview of theories and models which can be used to analyse regional development as well as to design policies and strategies for the future of regions and localities. It evaluates the analytical and policy relevance of these models, and as it moves towards analytical synthesis, makes some recommendations for a structural realist approach to spatial development analysis. It offers a methodological framework for contemporary spatial development analysis by combining regulationist, cultural political economy and network theoretical approaches, and taking full cognisance of the structural-institutional, scalar and cultural dimensions of development processes and strategies.
\end{abstract}

Keywords: Territorial Innovation Models - New Regionalism - regional development - path dependency - social structure, institutions and culture - Structural realism. JEL Classifications: $\mathrm{B} 0, \mathrm{R} 0$.

Analyser l'aménagement du territoire: une façon structuralo-réaliste.

Moulaert \& Mehmood

Cet article fournit une vue d'ensemble des théories et des modèles à employer afin d'analyser l'aménagement du territoire aussi bien que de mettre au point des politiques et des stratégies en faveur de l'avenir des régions et des endroits. On évalue l'importance analytique et de politique de ces modèles et, au fur et à mesure que l'on commence à penser une synthèse analytique, on fait quelques recommandations en faveur d'une façon structuralo-réaliste pour analyser le développement géographique. On propose un cadre méthodologique pour analyser le développement géographique contemporain en associant des façons réglementaires, d'économie politique culturelle, et théoriques de réseaux, tout en tenant compte des aspects structuralo-institutionnels, scalaires et culturelles des processus et des stratégies de développement. 
Modèles d'innovation territoriale / Nouveau régionalisme / Aménagement du territoire / Sentier de dépendance / Structure sociale, institutions et culture / Réalisme structurel

Classement JEL: B0; R0

\title{
Analyse der Regionalentwicklung und Politik: ein strukturell-realistischer Ansatz
}

FRANK MOULAERT and ABID MEHMOOD

\begin{abstract}
Dieser Artikel enthält eine Übersicht über die Theorien und Modelle, die sich zur Analyse der regionalen Entwicklung sowie zur Gestaltung von Politiken und Strategien für die Zukunft von Regionen und Orten heranziehen lassen. Wir analysieren die analytische und politische Relevanz dieser Modelle und machen beim Übergang zur analytischen Synthese einige Empfehlungen für einen strukturierten, realistischen Ansatz zur Analyse der räumlichen Entwicklung. Der Artikel bietet einen methodologischen Rahmen zur Analyse der aktuellen räumlichen Entwicklung, indem er die regulationistischen, kulturpolitischwirtschaftlichen und netzwerktheoretischen Ansätze miteinander kombiniert und zugleich die strukturell-institutionellen, skalaren und kulturellen Dimensionen der Entwicklungsprozesse und -strategien vollständig zur Kenntnis nimmt.
\end{abstract}

Keywords:

Territoriale Innovationsmodelle

Neuer Regionalismus

Regionalentwicklung

Pfadabhängigkeit

Sozialstruktur, Institutionen und Kultur

Struktureller Realismus

JEL Classifications: B0, Ro.

Análisis del desarrollo y la política regional: un enfoque realista estructural FRANK MOULAERT and ABID MEHMOOD

Abstract

Este artículo contiene un resumen de las teorías y los modelos que pueden servir para analizar el desarrollo regional y diseñar las políticas y estrategias para el futuro de las regiones y localidades. Evaluamos la relevancia analítica y política de estos modelos y según se va desplazando hacia una síntesis analítica hacemos recomendaciones sobre un 
planteamiento realista y estructural para el análisis del desarrollo espacial. Aquí ofrecemos una estructura metodológica para el análisis contemporáneo del desarrollo espacial al combinar enfoques regulatorios, de la economía política cultural y planteamientos teóricos de redes a la vez que intentamos reconocer completamente las dimensiones institucionales-estructurales, escalares y culturales de los procesos y estrategias del desarrollo.

Keywords:

Modelos de innovación territorial

Nuevo regionalismo

Desarrollo regional

Dependencia de rutas

Estructura social

Instituciones y cultura

Realismo estructural

JEL Classifications: B0, R0.

\section{Introduction}

With the rise (or the 'return'?) of 'Regionalism', the study of regional development and policy has once again become a major focus in social science spatial analysis. To benefit fully of the long tradition of research in this field (say starting with the German Historical School in the $19^{\text {th }}$ century), an equilibrated use of 'old' and 'new' epistemological stances and of ' back to basics' regional analysis are needed - the latter being a plea by Lovering $(2001)^{\mathrm{i}}$. We intend to situate our reading of the literature and search for a new synthesis within a critical-realist approach to society and its spatiality (SAYER, 1992), because such an approach offers a critical and open perspective on the factors and dynamics of social reality, allowing for diversity and complementarity of explanation but still recognising some 'structures with power' within society. The features of the criticalrealist approach, as summarised by Sayer (see endnote $i i$ ), stress that "the view of the 
world is differentiated and stratified consisting not only of events but objects, including structures, which have powers and liabilities capable of generalising events". ii Other features we stress here refer to the independence of reality from our knowledge; the fallibility and theory-based character of knowledge; the production of any other kind of knowledge as a social practice - realism thus clearly requires a 'sociology of knowledge perspective'. Structural realism (SR) then, as a particular focus within realism recognises a relative hierarchy among the objects of social reality and recognises structures in the form of relatively durable social relations as being of a potentially higher causal order. This does not mean that structures are pre-existing to social phenomena; in fact, structures are institutionally mediated and historically as well spatially reproduced through both collective and strategic individual action. Still the conceptual nature of structures, institutions and agency is pre-informed by the theory that has analytically conceived them. This means that within a critical-realist perspective several theories referring to the same or cognate concepts should be confronted and brought into dialogue with each other. A theory privileging the analysis of structures in social reality can also serve as a meta-theoretical framework, which sets in a way the borderlines within which particular objects and their relations can be analysed. Examples of such approaches are well-known in critical geography and spatial development analysis, where the metatheoretical framework adopts the social structures analysed in political economy - and often identifies them as a main feature of its social ontology - but, as in radical political geography, attributes them a deep spatial character (STORPER and WALKER, 1983; MOULAERT, 1987). The critical-realist perspective then requires that, within this framework, theories with different highlights and causal foci will communicate with each 
other and shed light on the different social phenomena and structures that explain regional development and policy. Certainly history plays a significant role in structural realist analysis. Relations between objects, the meaning of cultural change, the conditions and social relations of scientific activity and how it has affected progress or stalemate in society can only historically be laid out.

Having spelled out the epistemological premises of structural-realism, we shall now move to applying these to the review of the regional development literature, starting with the contemporary new regionalism models of territorial innovation, and subsequently work toward a new meta-theoretical synthesis for regional development analysis at the end of the article. Over the last twenty years regional development has been addressed mainly through the bird's eye view of territorial and especially regional innovation models, the spearheads of the so-called 'new regionalism' movement (MOULAERT and MEHMOOD, 2008). These models, discussed in section 2 as Territorial Innovations Models (a generic or family name for Industrial District, Milieu Innovateur, Learning Region, among others; see section 2 for details), were a significant advance on neoclassical regional growth analysis because they enabled the filling of the 'black box' the institutional dynamics of development - traditionally left untouched by neoclassical economics (MOULAERT and SEKIA, 2003). However, territorial innovation models (TIMs) go only half way in solving the methodological problems in regional development and policy analysis. ${ }^{\text {iii }}$ 
This appears from the epistemological reductionism of TIM (a capitalist market economic ontology; collapse of past and future perspectives, empirical and normative stances, institutions and structure, cultural and economic norms) means a backwards step compared to previous regional development theories. Therefore section 3 argues in favour of a return to the 'old' institutionalist tradition of regional development analysis (German Historical School, Gunnar Myrdal, François Perroux, the French school of disequilibrated spatial development, radical geographers of the 1970s, etc.), which by their particular interest in institutions fill the gap between the structure and other objects of social reality. These Schools and authors are more advanced in distinguishing the analytical features of regional development from its design strategy; and by combining these analytical features with recent insights from cultural political economy and relational economic geography; their theories could be made useful relatively easily for contemporary analysis of regional development and policy. The final section is devoted to methodological reflections about the study of regional development. A brief exploration of contemporary attempts to accomplish new syntheses (based on territorial embeddedness, relational complexity, strategic coupling), leads to an explicit choice to connect Cultural Political Economy, Regulationist and 'empowered' network approaches in order to underpin regional development and policy analysis today. Such connection should indeed lead to the definition of a structural-realist meta-theoretical framework within which more issuefocused spatial theories can be brought into use.

\section{Territorial Innovation Models: what are they telling us? ${ }^{\text {iv }}$}


'Territorial Innovation Model' (TIM) are models of regional innovation in which local institutional dynamics play a significant role as catalysts (especially positive) in innovative development strategies. TIMs, as the flagships of New Regionalism, embody an institutional turn in regional development analysis which means a significant step in elaborating a SR approach. Most of these models address the following features of development and innovation as well as the relationships between them: the core of the innovation dynamics, the role of institutions, the view of regional development, culture, the types of relations among agents, and the types of relationships with the environment. Mainly three families of TIM can be identified ${ }^{\mathrm{v}}$. The first contains the Milieu Innovateur and the Industrial District model. The French model Milieu Innovateur, which was the basis for the synthesis produced by GREMI (AYDALOT, 1986), stresses the role of endogenous institutional potential in producing innovative dynamic firms. The same basic idea is found in the Industrial District model, which focuses even more on the role of co-operation and partnership within the innovation process (BECATTINI, 1987). The second TIM family contains models belonging to the tradition of the Systems of Innovation: a translation of institutional co-ordination principles found in sectoral and national innovation systems onto the regional level (EDQUIST, 1997) or, more properly, an evolutionist interpretation of the regional learning economy within the regional space (COOKE, 1996; COOKE and MORGAN, 1998). The third TIM tradition stems from the Californian School of Economic Geography: the New Industrial Spaces (STORPER and SCOTT, 1988; SAXENIAN, 1994). In addition, there is a residual category, encompassing 'spatial clusters of innovation', which is not really another TIM family, as it has little affinity to regional analysis but lies close to Porter's clusters of innovation. 
All these models share a large number of key-concepts that have been used in regional economics or analysis for a long time, or that have been borrowed from other disciplines, especially in social science.

Table 1 summarizes the meaning of territorial innovation and its features in most of these models ${ }^{\mathrm{vi}}$. The learning region model has not been included because it can be considered as an essential synthesis of the features of many of the other TIM models.

\section{INSERT TABLE 1 ABOUT HERE}

Most TIM models stress the instrumentality of institutions in the economic restructuring and enhanced competitiveness of regions and localities. But in none of these models is reference made to improving non-economic dimensions and non-market led sections of regional and local communities, unless such improvements could contribute in some way to the competitiveness of the territory. According to the TIM, quality of life in local and regional communities depends on growth of prosperity and will appear as a positive externality of higher economic growth; no distinction is made between wellbeing and growth, between community culture and business climate.

There is no doubt that TIMs take a significant step forward when compared to orthodox models of spatialised economic 'development' (e.g. neo-classical regional growth models) in that they recognize the explicit role of institutions (including firms) and their learning processes as key factors in economic development. In this way, they fill the 'black box' of the neo-classical model of the firm and its networks which disregards the 
institutional dynamics of innovative agents, and only considers the logic of rational economic agency. TIMs are therefore more socially sophisticated than neoclassical regional growth models, for they perceive institutional dynamics (culture, learning organizations, networks) as improving the market-competitiveness of the local economy. (In orthodox development discourse, one could say that they make 'development' functional to 'growth'; the neo-classical adage turned upside down!). But at the same time TIMs reflect a societal ontology with a restricted view of economic development: innovation and learning will improve the market-economic performance of a region or a locality, and in this way will contribute to the achievement of other developmental goals (economic, social, political, cultural).

In other words: implicitly, TIMs do not consider either the multi-functionality or the allocative diversity of the 'real' economy - an economy that is in reality much broader than the capitalist market economy - or the other existential (non-economic) spheres of local and regional communities, such as the natural environment, the social-cultural (artistic, educational, social services) and the socio-political sphere. Despite their devotion to institutional dynamics, they are sworn to a market-based economic ontology and technological view of development. They blatantly overlook the past and present role of the structural mechanisms of growth and decline, even and uneven inter-regional exchange and development mediated by these institutions and their strategic agencies (HOLLAND, 1976). One could argue that in the TIM view of institutionalisation, the 'lightness of being' of the rationalist behavioural perspective transforms the institutional complexity of the real world and its development paths into self-evident path-breaking 
strategic behaviour - thus rationalising history as if it would be organically engineering the innovative future!

Contrary to a structural-realist perspective the connections between agency, rationality and social relations have also been narrowed down to the latter's functionality for rational economic behaviour pursuing improved competitiveness for the regional or local economy. Another ontological aspect of the market-economist and instrumentalist view of institutional dynamics inherent in TIM is the narrow view of regional economic development policy. In tune with the TIM ontology, economic policy sectors are honed by prioritising technological innovation and rationalist learning procedures, while other sectors are geared towards market-led economic policy. Cultural, educational, transportation, urban development policies, etc. all become more or less subjugated to market competitiveness and lose the raison d'être and policy purpose specific to their own logic in contributing to the cultural, educational, environmental emancipation of human beings and their social groupings (MOULAERT and NUSSBAUMER, 2005).

Finally TIMs suffer from what we could call a 'localist trap'. For a variety of reasons, they regard regional and local development strategies using endogenous resources as the appropriate answer to the uneven and unequal consequences of globalization and power strategies of global players (see for a critical perspective DUNFORD and GRECO, 2006). This position waters down into a naïve misjudgement of the role of the latter and into an unbalanced view of how realistic regional development strategies should take into account both global players and especially their 'focal firms' (COE et al., 2004); at the 
same time this denial of the 'evil of the global', leads to an unrealistic understanding of the power of endogenous resources and how these have been managed. It would, for example, be interesting to apply this perspective to Hassink and Lagendijk's (2001) observations on the 'scant attention to interregional dimension of learning' contrasting with the strong focus on regional learning in regional development analysis. In its most extreme reading the 'localist trap' also means that TIMs are defined in economic and political isolation from the outside world. Old insights (see section 3) that TIMs can only be successful thanks to economies of scale (and not only of scope as TIM do recognise) and high-value added trade networks, and that regions and localities are competitors within a wider economy and polity - with the risk that in absence of appropriate national and supra-national development policies only a limited number among them will succeed - and that macroeconomic dynamics and policy affect the regional development potential seem to have been forgotten (AMIN, 1999). True, contemporary new regionalism analysis is more realistic about this and "places increased weight on extra-local dynamics shaping economic growth within regions" (COE et al., 2004, p. 469); but it remains an enigma why today, in order to bring 'new regionalism' back to this level of geographical complexity, established verities of the 1970s about path-dependency and the meaning of wider spatial scales for development had to be reinvented from scratch.

\footnotetext{
These ontological positions of TIM have inspired at least two major epistemological miscarriages which affect these models' utility for working towards a structural-realist methodology for regional development and policy analysis.
} 
First, TIMs do not manage to disentangle normative from analytical perspectives in regional development research. In realism terms, they neither consider discourse and norm systems as socially produced, nor do they distinguish the specificity of cultural practices. The most significant consequence of this is that intentionality of change in agency' (e.g. innovative strategies, improved organizational learning) is taken as the main driving force of actual regional development. This leads recurrently to a situation in which real-life strategies are analysed as 'imagineered' future behaviour, as if the past and present of regional development can be explained only as the result of rational innovative behaviour within effectively organised learning processes (MOULAERT and SEKIA, 2003), or to a homogenised view of 'best practice' innovation strategies across different types of regions, irrespective of their development path - as rightly criticised by Tödtling and Trippl (2005).

Second, despite TIMs' significant contribution to re-institutionalising the study of territorial development, their analysis of institutional dynamics is framed by the instrumental interpretation of 'territorial institutions for market-led growth' and by what Hess (2004) calls an over territorialized view of embeddedness. This leads for example to either an over deterministic explanation of the role of globalization or a naïve understanding of the width of the manoeuvring space left to endogenous strategies within the global economy and society (DICKEN, 1994).

To overcome these epistemological flaws in the explanation of regional development and policy, we turn in section 3 to 'older' and/or more 'cultured' theories that offer clearer 
explanations of the relationship between past, present and future; agency, structure and institutions; institutions and culture; and development and policy. These theories, therefore, hold potential for developing a structural-realist perspective to this explanation.

\begin{abstract}
More recent attempts to overcome the devotion to local endogeneity and the neglect of articulation between spatial scales have been made by the 'strategic coupling' approach (COE et al., 2004), the revisiting of 'relational economic geography' (YEUNG, 2005), the contextualisation of the territorial embeddedness approach (HESS, 2004) and the path-dependent definition of local development strategies (COX, 2004). These we deal with in the later section 4 , as a spring-board for the presentation of our analytical synthesis.
\end{abstract}

\title{
3. Old-timers on regional development
}

We have seen in section 2 that in contemporary literature on regional development 'new regionalism' and TIMs are playing the first violin. But we noticed that these models suffer from ontological and epistemological reductionism: they use idealised categories of design strategies for future development also as key categories in the analysis of the structural and institutional dynamics of the past, hence short-cutting the causality relations between agency-institutions-structure; and they prototype regional development policy as almost exclusively targeting improved competitiveness. To this end they search for good or best practice combinations of technology and organization, supported by regional and local institutional catalysts. They also tend to overlook the effectiveness of non-economic factors and institutions in regional social and economic 
development (HADJIMICHALIS, 2006). Most TIMs refer to a path dependency of regional development which is usually limited to the continuity of culture patterns and modes of social association between innovative agents and which does not consider the constraining or incapacitating impact of the historical paths followed by the so-called 'abstract' structures of the capitalist economy (division of labour, wage labour relationship, competition between capitals and market structures).

In this section we briefly survey 'old timers' which in their days did not fall victim to institutional instrumentalism and selective a-historicism as we have observed in TIMs. We successively look at Historicism, the schools of disequilibrated growth, and radical economic geography. In the latter part of the section, we also turn to recent contributions in Cultural Political Economy which can be considered as bringing a new dimension to regional development analysis, e.g. by distinguishing different dimensions of cultural practice, important to fulfilling a structural realist perspective.

\subsection{Historicism and territorial development}

The German Historical School has been the basis of the development of $20^{\text {th }}$ century economic growth and development theory. ${ }^{\text {vii }}$ GHS contributions to a better understanding of the Nazionalökonomie and the various analyses of the stages of economic growth have had a major impact on later national and regional development theory and analysis. However, post WW II 'stages of growth' theory can only be indirectly connected to the German Historical School, mainly because the German literature was not well-known to Rostow and others, and also because of the influence of the British classical school on the 
rise of the 'stages of economic growth' analyses which transformed the reading of historical development into a time-series record of economic growth performance indicators (HOSELITZ, 1960). A significant difference between the GHS and the Classical Economists is that the GHS already offered a real theory of economic dynamics (e.g. the idea of cumulative causation) whereas the Classics only provided principles for economic dynamics (such as the role of the changes in the division of labour following Adam Smith) while maintaining the view of an organic tendency towards equilibrium both of the economy and among its agents. ${ }^{\text {vii }}$ The GHS contributed to the making of territorial development analysis in the following three ways:

\section{- The recognition of the growing role of the state and the industrialisation}

Nussbaumer (2002) demonstrates that significant numbers of ideas found in post Second World War literature on local and regional development were already present to some extent in the writings of the German Historical School. For example, the focus on the social dynamics of development, connected to the building of the Nation State from the different German states; social relations between the Nation-state and economic development; and, the culturally embedded socio-economic organisation of economic activities, have all been active features of discussion in the GHS literature.

- Space as a historical category 
Gustav Schmoller's writings $(1884 ; 1905)$ have applied historical embeddedness to spatial analysis. Using an anthropological perspective, he showed how society appropriated space through the development of institutions that organise it according to the needs of the population. In other words: spatial institutions materialise the social relations that are developed in a community. Therefore, the evolution of needs and the economic system implies a transformation of the institutional configuration of space. The relative importance of institutional levels varies according to their relevance for the development of the (regional, local) community. However institutional evolution is not uniformly harmonious but produces conflicts. Power relations, both within and between institutions, form part of a dialectical movement. The interrelations between economic actors illustrate the political dimension of development; for instance those who try to influence policies by integrating town councils, and political powers that try to orient and promote economic activities. Space, considered from the perspective of its appropriation through (re)institutionalization, is embedded in the movement of history.

- Spatial and territorial approach

The GHS territorial approach to development was mainly developed by Gustav Schmoller. He showed how competition and cooperation within and between institutions are important in creating opportunities for political intervention and for interaction between political action and the transformation of the economic system. This idea, linked to the emphasis on the combination of development factors necessary to generate development and the recognition that social relations within a group or community are 
part of the development process, leads to an analysis of development that links market mechanisms to social interaction.

The contributions of the GHS have had a remarkable influence on the development of later theories of regional endogenous development. Especially, its methodological contributions such as the interactive analysis of causality and its significant impact on methodological collectivism show its affinities with structural realism. And it has also had an impact as one of the pillars of the Regulation Approach (VILLEVAL, 1995) which we deal with in section 3.3.2.

\subsection{Embedded regional development and cumulative disequilibrium}

In the 1960s (or late 1950s) the simultaneous discovery of the difficulties of development in the South and of regional and local problems of development in industrialised countries due to massive transformation of the industrial system (HIRSCHMAN, 1984), highlighted the significance of spatial scales of development and their diversified political and economic dynamics.

However, it would be illusionary to think that a smooth inter-paradigmatic path of scientific progress led from the GHS scholars to the spatial development analysts of the 1960s. In the first half of the $20^{\text {th }}$ century a rupture in the analysis of spatial development [and location] came with the rise of neoclassical location and central place theory. There were many reasons for this paradigmatic discontinuity, of which we cite only the few most important: (i) US scholars' (who until the Interbellum frequently trained at German 
universities) disapproval of German imperial policy - especially under the Nazi regime led to a loss of interest in the GHS that was strongly focused on the role of institutions in general and the State par excellence; (ii) the euphoric spread of positivist scientific methods in social science. Positivist methodology development was invigorated by the rise of formal location analysis, already present at the end of the $19^{\text {th }}$ century, especially in Germany, which began to overrule the GHS approach by the second quarter of the $20^{\text {th }}$ century. We would have to wait till 1980s for a 'mainstream' critical realist answer to the dominant positivist methodology in social science in general, and spatial development analysis in particular.

Gradually a growing separation occurred between pseudo-classical or neo-classical location theory and regional growth theory on the one hand, and institutionalism-rooted regional development theory on the other. The latter includes authors like Myrdal (1957), Hirschman (1958) but also François Perroux (1955; 1983; 1988). Perroux is especially remembered for his analysis of the relationships between economic agglomeration on the one hand (growth poles within geographical space) and externalities (technological, pecuniary) and power relations on the other; his growth pole and regional development analysis adopts a strong institutional perspective and shows how unevenness in economic relations is institutionally confirmed, with only well-established public policy being capable of countering uneven development.

An interesting novel presentation of Myrdal's work on spatial socio-economic development is given by Meardon (2001) who argues: 


\begin{abstract}
"In sum, Myrdal's theory of agglomeration was part of a holistic alternative research program. Its main components were a critique of predominant economic theory, the development and interdisciplinary application of the concept of cumulative causation, and the proposal of public policies intended to reduce international, interregional, and even interracial inequalities - all founded upon explicitly stated value premises.” (p. 49).
\end{abstract}

For our purpose the 'application' of Myrdal's cumulative causation framework to regional and interregional development is of particular interest. He discusses cumulative causation in terms of a tension between backwash and spread effects. He explains how agglomerations often originate as a consequence of either a single or a few economic initiatives (historical accidents) but that their development and dominance over lesser centres is a result of ever increasing internal and external economies in the growth centres. Cultural and political processes play a significant part in this, and the increasing inequality between growth and lesser centres can only be overcome by active and sustained public initiative (MYRDAL, 1957).

The confrontation between these institutionalist regional development analyses and the new regionalism is instructive and shows how the latter has simplified the 'regional world' into an agency space combining institutional and economic engineering - far removed from the real spaces of cumulative causation of growth and development in leading regions and localities, where political power-broking and unequal exchange based trade and investment networks play a significant part. This analysis of Myrdal and others also provides arguments explaining why worldwide maybe a thousand rather than 
a million TIMs will flourish within the real global world and how successful regions will extort resources (human capital, innovative ideas, finance capital) from less successful or poorer regions. ${ }^{\text {ix }}$

\subsection{Political economy of regional development ${ }^{x}$}

The political economy of regional development examines the deployment of the relations of production both within and as reproduced by the 'systems of regions'. Two influential analytical frameworks have been developed quasi simultaneously by Doreen Massey (1984) and Lipietz (1977). Both look at the articulation between the (spatial) hierarchy of the division of labour on the one hand and the reproduction of regional inequality on the other. Later contributors such as Markusen (1983) and Hudson (2001) have broadened the concept of social relations and its role in the analysis of the regionalization process and thus attributed more value to non-reductionist interpretations of regional development; and Sum (2006) has valorised the potential of a more culture-enhanced approach to regional development. These and other authors have stressed the need for better articulation of the different social processes through which space is constantly reproduced - and thus de facto executing Lefèbvre's concept (1974) in which he distinguishes between perceived, conceived and lived space and paves the way for a more counter-hegemonic, lived-diversity based approach to spatial development strategies.

\subsubsection{The spatial division of labour}

In his book 'Le capital et son espace', Alain Lipietz (1977) develops a Marxist theory of regional development. It combines an explanation of the regional inequality problem in 
terms of the condition of the rural economy in France with a spatial division of labour model of manufacturing and service activities across the space-economy. To do so Lipietz analyses 'interregionality' ("les rapports qui s'établissent entre régions inégalement développées au sein d'une zone d'intégration articulée en circuits de branches desservant un marché unique", p. 84) on the basis of the flows or circuits of the branches of production. For this purpose he examines the articulation between 'pre'capitalist relations of production - especially as materialised in traditional agriculture - and the capitalist relations of production as expressed in manufacturing [especially fordist] branches of production. Lipietz analyses explicitly both the development of, and the articulation between, modes of production within the complexity of state - capital relations (i.e. the complexity of national social formations, regional armatures and the over-arching 'imperialist multinational bloc'). He establishes a hierarchical typology of regions: central, intermediary and peripheral. His original empirical basis for this work is the spatial development of industry in relation to agriculture in France; later he completes his analysis using evidence from the regional development of the service sector, which he considers as a further though partial expression of the permanent laws of capital accumulation (concentration, agglomeration of capital, deskilling of direct producers, etc.) and which he links to the deskilling industrialisation of metropolitan regions both internally and at their peripheries (LIPIETZ, 1980: 68).

Doreen Massey's analysis of divisions of labour and the reproduction of uneven spatial development in the UK has strong parallels with Lipietz's in France. Massey (1984: 67): 
"If the social is inextricably spatial and the spatial impossible to divorce from its social construction and content, it follows not only that social processes should be analysed as taking place spatially but also that what have been thought of as spatial patterns can be conceptualised in terms of social processes. [...] The primary social process which the geography of jobs reflects is production. The spatial distribution of employment, therefore, can be interpreted as the outcome of the way in which production is organised over space."

Then Massey develops the argument that the social relations of production are necessarily deployed in space and in a variety of forms, which she calls spatial structures of production. Such spatial structures, although often similar across social spaces, should never be considered as archetypes, deterministically reproduced through the reproductive dynamics of capitalism. Instead the geographical forms of the organisation of production should be examined empirically. In capitalist production systems two distinct types of hierarchies quite often overlap and reinforce each other: (i) the managerial hierarchy comparable to Hymer's (1972) control structure linking headquarters to subsidiaries and branch plants; (ii) the hierarchy of the production process itself with R\&D (often) separated from it; and the production process itself consisting of the production of technically more complex components (engineering) as well as the final assembly of commodities. Massey stresses that, in most cases, a country's national economic geography - perceived as the ensemble of geographical forms of the organisation of the 
economy - "reflects its position in the international political economy, the international division of labour" (p. 82-83).

Both Lipietz and Massey keep underlining that the reproduction of social space is not a one-way causal outcome of the organisation and reproduction of the capitalist production system. Massey: "Spatial structures are established, reinforced, combated and changed through political and economic strategies and battles on the part of managers, workers and political representatives" (p. 85) Political struggle will ultimately determine these forms. However national territories and their spatial organization significantly reflect the unevenness embedded in the corporate hierarchies, be it manufacturing firms (HUDSON, 2001) or service providers and their networks (MARTINELLI and MOULAERT, 1993). But the material outcome of this use of space will ultimately depend on capital-labour relations within the regional system, the strength of the unions and the strength of the class-balance of the State apparatus.

\subsubsection{Cultural and socio-political dimensions of regional development}

Observe that these analyses of regional development, although attaching significant importance to social relations and regulation (especially by the State), still employ an economic interpretation of social relations and their spatial forms. Later work, often influenced by Lefèbvre (1974), such as the regulationist analysis of spatial development (LEBORGNE and LIPIETZ, 1990; MOULAERT, SWYNGEDOUW and WILSON, 1988; MOULAERT and SWYNGEDOUW, 1989; MOULAERT, 1995) and gender and diversity literature (see e.g. BLUNT and WILLS, 2000) broadens the whole idea of social relations in space, and shows how different conceptions of space lead to a better 
understanding of regional development, its potential opportunities and how these feed into the development paths and visions of past and present.

Lefèbvre's generic work on the production of (social) space has had a determining influence on spatial analysis across most disciplines. In his Marxist approach to space, Lefèbvre contrasts perceived, conceived and lived space and addresses the spatial character of each of them by distinguishing spatial practices, representations of space, and representational spaces. Although he stresses the relations of production and their spatial deployment when applying these trialectics to capitalist society, his approach, more than that of Lipietz and Massey, leaves all doors open to look beyond 'abstract' space created by capitalist dynamics, and to include [other than production] social relations, representations of space and representational spaces involved in the reproduction of society and the interaction between hegemonic and counter-hegemonic movements. However, Lefèbvre never breaks the links between production relations and other social relations in society.

In recent years several contributions to regional development analysis have used a broader perspective on social relations, addressing their diversity and their cultural as well as structural dimensions. We cite four contributions in particular:

- Markusen's (1983) work on Regionalism and Regional Development: Markusen explains how territorially defined regions are relevant to political economists when conflicts in social relations of production are perceived as regional conflicts by the actors involved. She calls this perception regionalism, "the espousal of a territorial claim by 
some social group", or in the case of a political movement "the political claim of a territorially identified group of people against one or several mechanisms of the State..." Although 'regionalism' for Markusen is clearly a subjective and experiential term, it can also refer to objective social dynamics that cause territorial differences in social formations. In this way it may refer to the different social relations and institutions which embody or govern relationships within the human community: the household, the State, and cultural institutions.

Because the term region, warns Markusen, "connotes a territorial, not social, entity," its use can lead to a number of epistemological (including conceptual) errors. First, region might be confused with all social relations that are territorially based. As such, a class conflict or a conflict between cultural groups might be wrongly perceived as a conflict between regions (Markusen gives a number of examples). Second, it is probable that the existing territorially defined regions (state, cultural identity, natural habitat, etc.) are only partially relevant to the spatiality of the social relations determining the dynamics of social reality in the region.

Although Markusen explains very well how territorially defined regions can be an issue in political economy, a regional issue itself can only be fully understood if the spatial expression of the social relations - that is, the spatial organization of which the region forms a part - is fully understood also. Markusen's framework recognises the diversity of social relations - beyond strict confinement to (social) relations of production - and thus is highly significant for the analysis of the spatial nature of social and economic development within and across regions and localities. 
- Gender and Diversity. The inclusion of gender and diversity (using a multi-ethnic perspective for example) together with the role of the wage-labour relationship in the analysis of regional development have enriched the understanding of the role of female and migrant labour in regional labour markets (MASSEY, 1984), the uneven reproduction of patriarchal professional hierarchies (MULLINGS, 2005) and the design of alternative emancipation and spatial development strategies (BLUNT and WILLS, 2000).

- Regulation Approach and Local/ Regional Development: The 'territorialization' of the regulationist approach has reinvigorated the debate on the analytical (and strategic) weaknesses of regulation theory and contributed to overcoming them (LEBORGNE and LIPIETZ, 1990; MOULAERT, SWYNGEDOUW and WILSON, 1988; MOULAERT and SWYNGEDOUW, 1989; MOULAERT, 1995; PECK, 1996; PECK and TICKELL, 1992). Reformulating regulationism, after a refreshing territorial bath, is meant to enable this at first National Social Formation oriented analytical framework to address regional development. The revisited regulationist approach includes: (i) an articulated time-space approach to subsequent modes of development and their concrete forms; (ii) a greater focus on the impact of non-economic structural dynamics on regional and local development; (iii) the broadening of the reading of regulatory dynamics from 'pure economic' and 'state agency' to different types of formal and informal regulation; (iv) redefining the role of agency and behavioural codes within the broader definition of institutional dynamics; (v) a reading of social reproduction at the local and regional level which is both extensive and respecting of diversity, and is in tune with recent insights on 
the role of culture, gender and diversity in spatial development strategies, institutionalization and structural transformations; (vi) the recognition of power relations together with social and political struggle as critical analytical categories in regulation theory (MOULAERT, 2000). These improvements to the Regulationist Approach within the territorial regulationist approach resonate with most of the concerns about the onetrack approach of political economy, i.e. overemphasis on the determinist explanatory power of the social relations of production, and how to overcome them, and also several of the concerns of a structural-realist approach to regional development analysis. Not covered in this corrigendum, however, is the role of discourse both in reproducing culture and as a 'real' strategy, which has been a concern of the cultural political economy approach to socio-economic development, but also addresses the cultural concerns of the realist approach.

- Cultural Political Economy and Discourse: Recent work on the relationships between Culture, Discourse, Identity and Hegemony (CDIH) has laid the foundations for an improved integration of two analyses: the analysis of social and cultural embedding of agency and the social construction of institutional change (the 'pure' cultural turn in social science) as well as the more 'structural-materialist' social science analysis stressing the historical specificity and material effectivity of economic categories and practices as applied by e.g. the Regulation Approach or the Strategic-Relational Approach (SUM, 2006; 2005; JESSOP, 2001; JESSOP and SUM, 2006; SUM and JESSOP, 2007). According to Sum (2006) "The CDIH model [within the cultural political economy approach] seeks to develop a more balanced approach that pays due 
attention to the material-discursive nature of social relations, albeit based on a more open conception of social structure (SMART, 1986; FAIRCLOUGH, 1992; JESSOP, 1990; GIBSON-GRAHAM, 1996), as well as to the strategic-discursive moment that is associated with the textual or semiotic aspects of social relations and their emergent properties." (p. 6). Over the last few years Cultural Political Economy (CPE) approaches have enriched regional development analysis by focusing on the role of discourse and identity-building in defining regional and urban policy and interpreting 'histories' of regions and cities. The most promising of these applications are based on the integration of critical discourse analysis into variants of the regulation approach that retain strong residual elements of the Marxist critique of political economy. In this way, CPE takes the cultural turn, with its emphasis on discursive-strategic questions, in the analysis of socioeconomic development without sacrificing the lessons of a materialist-structural analysis of the historically specific socio-economic dynamics of capitalist economies. Following Sum (2005) this integration examines the development of economic imaginaries and associated grand narratives at various interlocked spatial scales; and also explores how these imaginaries and narratives facilitate the emergence and consolidation of not only hegemonic systems (of which they are also an important moment) but also of counterhegemonic movements. Economic imaginaries involve spatio-temporal horizons of action and are institutionalized in specific spatio-temporal matrices and, as such, have major implications for spatial development. In particular, they have a significant impact on how regulation and strategic agency are reproduced at the regional and local level. Moreover, the modes by which grand discourses are reproduced via struggles at the global and national scales are highly relevant in coming to grips with the role of discourse in 
reproduction and accumulation at the local and regional level. Interesting illustrations of this approach are Hajer (1995), Sum (2002) on Hong Kong, Gonzalez (2005 and 2006) for the Basque Country and Bilbao (Northern Spain), Raco (2003) on Scotland, McGuirk (2004) on Sydney, and Moulaert et al. (2007) in relation to urban redevelopment policy in Milan, Antwerp, Vienna and Naples.

One could summarize the discussion in section 3 by arguing that the 'objectivation' of social relations, the broadening of their conceptualisation from economic to social and to cultural dimensions as well as their historical and spatial embedding have made a major contribution to the building of a structural-realist methodology for regional development analysis. These analytical merits will be valorised in the next section, where we will work toward a new synthesis in regional development analysis.

\section{Methodological prospects: toward a structural realist synthesis for regional development analysis}

Over the last fifteen to twenty years the literature on regional development and regional development policy has been dominated by the New Regionalism approach and its Territorial Innovation Models, of which the most popular today is the Learning Region. Although New Regionalism did reintroduce the role of institutional dynamics and path dependency into regional development analysis, unfortunately, its analytical potential soon became constrained by a contemporary reading of the historical and institutional foundations of development, thus reducing path dependency to the reproduction of specific assets and institutions within local and regional communities. At the same time, 
the scalar geography of this approach overplayed the role of the local and regional territory at the expense of interdependencies with other spatial scales. By doing so, the opportunities or constraints stemming from globalization were often miscalculated, and the critical role of supra-regional governance - with still currently an important role for the National state - overlooked. As a consequence, TIMs have become idealised icons of development dreams instead of much needed models addressing the politics and policy of the possible (on the latter, see NOVY and LEUBOLT, 2005; SWYNGEDOUW, 2005). It is therefore of critical importance to move beyond new regionalism, and to develop an alternative perspective to regional development that manages to find a solution to most of the analytical shortcomings mentioned in the earlier sections of this paper. As explained in the introduction, we have opted for a structural realist approach to establish this perspective.

\subsection{Beyond New Regionalism}

Before moving on to our methodological synthesis for regional development analysis, we focus on some recent contributions to overcome some of the flaws of New Regionalism models. We address consecutively the approaches of strategic coupling, of social embeddedness and of relational geography.

Coe et al. (2004) explain how the strategic coupling approach offers a way out of the localist trap overshadowing new regionalism theories and Territorial Innovation Models:

"Drawing upon a global production networks (GPN) perspective and deriving insights from both the new regionalist and GCC (Global Commodity Chain) 
and GVC (Global Value Chain) literatures, our approach focuses on the dynamic 'strategic coupling' of global production networks and regional assets, an interface mediated by a range of institutional activities across different geographical and organizational scales. Our contention is that regional development ultimately will depend on the ability of this coupling to stimulate processes of value creation, enhancement and capture.” (p. 469)

Notwithstanding the fact that the strategic coupling approach offers a major corrigendum to the most localist among the TIMs, it is not really as successful as it pretends in analysing regional development as a set of relational processes. Although we support a process view of regional development, in our opinion processes involve more than relational dynamics as they have been analysed in the relational geography approach.

Two other recent contributions from (economic) geography have scrutinised 'spatial' relationships in development. The 'social embeddedness' approach attempts to bypass the limits of territorial embeddedness - often implicitly assumed in many TIMs. Hess (2004) seeks to do so by illuminating the concept of 'embeddedness'; first by explaining the evolution of embeddedness in Karl Polanyi's work and then moving on to Granovetter's distinction between relational and structural embeddedness, with "the former describing the nature or quality of dyadic relations between actors, while the latter refers to the network structure of relationships between a number of actors" (p. 170-171). Two observations should be made on Hess' synthesis of the 'rescaled' embeddedness approach: it overcomes the local scale bias of embeddedness in a positive way (social embeddedness occurs at related spatial scales); but unfortunately it clings to an 
'interactive' interpretation of social structure - in fact it uses a definition of social structure as 'interactively constructed', not historically and 'societally' reproduced.

A similar observation can be made about Yeung's (2005) critical survey article on relational economic geography which is both illuminating and debate provoking. Yeung inspired by Jessop (2001) - rightly points out that the recent relational turn in economic geography is mainly a thematic one and that an ontological-epistemological relational turn is still to come. He connects the recent popularity of relational thought in economic geography partially to the analytically limited (presumed) structural determinism of Social Relations of Production (and Spatial Division of Labour; see section 3.3.1 above) that leaves little room to analyse mid-range institutionalisation and micro-agency. He compares three recent thematic turns in relational geography: (i) regional and local development as a function of synergised relational assets; (ii) relational embeddedness in networks; (iii) relational scales. (i) coincides largely with the theoretical approach used in the New Regionalism/TIM approach while (ii) matches the 'social embeddedness' line of analysis summarised and revisited by Hess. But (iii) in our opinion offers a misunderstanding of the meaning of the scalar articulation approach. Swyngedouw, Peck, Brenner etc. do not offer a relational geography approach - at least not in the interactive interpretation of relationality which Yeung attributes to these authors - but make a successful attempt to overcome the scale problem of the reproduction of social relations in space (see especially SWYNGEDOUW, 1997). To do so, they improve mainly on the territorialized version of the Regulation Approach which, although it provides the analytical key to the spatial articulation approach, strangely enough is not mentioned in Yeung's article. This observation is not just hair splitting, but points to a significant 
distinction between the meanings of 'relationality' in the different 'relational turns' examined by Yeung. Indeed, for the authors of the scalar articulation approach, relationality refers to social relations in the political economy meaning of the term, and not to interactive dynamics as meant in both the new regionalism or social embeddedness thematic turn. A real 'methodological' relational turn should clarify this distinction, as it should also clarify the distinction in relationality between objects and as social processes. In the Political Economy and the Regulation Approach for example, social relations are not relations between objects but are social processes that are historically and spatially articulated. In consequence, they cannot be changed as a rule through the action of individual actors but through social forces such as (counter) hegemonic movements, institutionalisation processes, cultural upturns,... And they are different ontologically and epistemologically from the type of relationality studied in mainstream network analysis. More careful study is needed therefore of the types of relationality that are relevant to economic geography.

\subsection{Towards a meta-theory for regional development analysis}

To re-equilibrate the framework of regional development analysis, a return is necessary to the 'old' interpretation of institutional dynamics and structural relations. But to lead a comprehensive analysis of regional development these [rediscovered] structures as timeand-place robust institutions and mediated social structures should be combined with an interactionist view of relations between 'development' agents, the specificity of their agency and a cultural perspective on their agency and institutionalization. Keeping in mind the concerns of the SR approach presented in section 1, this synthesis can best be 
achieved by starting from a meta-theoretical framework as suggested by Storper and Walker (1983) and Moulaert (1987). Such a framework is based on a social ontology that includes 'empowered' structural relations in which the capitalist relations of production are dominant, but where 'other' social relations are part and parcel of the social process. This ontology comes quite close to that of the Regulation Approach - sometimes designated as a meta-theory by itself. However, as pointed out in section 3.3.2, the Regulation Approach misses several cultural dimensions and fails to recognise the relative autonomy of social relations in space-and-place. In addition it is poor in dealing with the social and cultural dynamics of agency and its micro-networks. We therefore argue here that to achieve an appropriate framework for regional development analysis, a number of 'open' theories fitting or fittable to the SR approach could be brought together. Open theories, can be considered as theories that denominate a limited number of structures, institutions or typical agencies, but do not provide specific theorisation of the causalities or relations between the objects they host. They can be combined into a metatheoretical synthesis, with a shared social ontology. The synthesis we defend here combines an Empowered Network Perspective (MOULAERT and CABARET, 2006) with a 'Culturalised' Regulation Perspective - an integration of a Regulation Approach with a Cultural Political Economy perspective (JESSOP and SUM, 2006; MOULAERT et al., 2007). Together, these offer a meta-theoretical framework that could host various contributions from old and new institutional and political economy approaches to regional development.

Our support for this meta-theoretical integration is based on our agreement with relational (socio) economic geography that relationality has many dimensions: interaction, 
embeddedness and scalar articulation; at the same time our endeavour is a reaction against the 'networkish' interpretation of relationality inherent in most relational geography applications, which stress the central role of agents as architects of networks and their institutions while overlooking the role of structural relations - as processes - in the reproduction of agency networks and their institutions. To calibrate this reaction, we appeal to a Regulation Approach but one upgraded from a Cultural Political Economy perspective, as argued in section 3 . This allows us to bring structural relations and power into the network metaphor, i.e. to empower network theory. Figure 1 here and the subsequent discussion reflect how a meta-theoretical foundation can be established.

\title{
INSERT FIGURE 1 ABOUT HERE
}

\begin{abstract}
Starting from a detailed reading of network analysis in evolutionary economics and organizational sociology, Moulaert and Cabaret (2006) argue that using the network metaphor as a concept for analysing real-life situations as basically the interaction between agents and the resulting outcomes, is a logical intellectual ambition:
\end{abstract}

\footnotetext{
"Human life, organizations and agencies are based on interactions between human beings that are to a large extent networked amongst themselves. Agents (individuals, organizations) develop and share cultures, modes of communication, principles of (network) action and ways of building institutions. These institutions will of course not just be the outcome of voluntary institutional engineering within the networks, but will also depend on the interaction between the network
} 
dynamics, the network environment and the development paths of the society and communities to which the network belongs. Thus network theory is useful in modelling strategies and policy actions in regional and local development." (p. 54).

Better than 'structural' social theories, the network metaphor, by looking at cognitive processes, the role of network culture and the production of discourse, offers a natural link to cultural political economy. However, most current network theories defend reductionist rational approaches to human behaviour (for a critique, see HADJIMICHALIS and HUDSON, 2006), stress the role of procedures in information gathering, exchange and institution building but deal very poorly with social structures, power and power-relations. To overcome this weakness, Regulation Theory can step in.

\begin{abstract}
Although Regulation Theory, like Marxism, primarily looks at economic (strategic) behaviour, its theorising of social and political structure as social relations focused on power relations and institution building as a social process, is relevant to 'empowering networks' within society. Similarly, property relations, labour-capital relations, finance capital, the State as an extended logic of capital, etc. play a direct role in most networks embedded in the socio-economic world. In network terminology, this means that stakeholders hold significantly unequal stakes, the decision-making space is limited or uneven, and, in extreme cases, the outcome of negotiation processes is known beforehand, because the structural-institutional impact of the logic of capital and politics is so influential. By using the embeddedness approach of Polanyi and Granovetter, we
\end{abstract}


could not only embed the network analysis of strategic behaviour and policy making by leading regional and local agents within the Regulationist Approach of social relations, but also use that approach to study the reproduction of the economic, political, social and cultural structures of the region and its localities (MOULAERT and SWYNGEDOUW, 1989).

These structures - together with the networks embodying their micro-dynamics - then become 'encultured', under the Cultural Political Economy's revisiting of social analysis by looking at the role of culture, identity and discourse and how they affect social forces and strategic agency. As indicated in section 3 the work of Sum $(2005,2006)$ in particular has been bridge-building in this respect. Inspired by Jessop (1990) and AngloFoucauldian theorists such as Rose and Miller (1992) and Dean (1999), Ngai-Ling Sum has designed a heuristic device that links the macro and micro processes - especially stressing the role of discourse - of hegemony and counter-hegemony making. In six interrelated moments that highlight the discursive dimensions of social relations and individual and collective agency, she provides the concepts necessary to analyse the relationship between 'real' and 'cultural' articulation via the examination of struggles involved in the material-discursive practices of everyday life. As shown in cited casestudies (section 3) this adds real value to the understanding of culture and discourse in regional and local development and policy.

As explained before we label the integration tripod of network theory, regulation approach and cultural political economy as a 'meta theoretical framework' because it 
provides a social ontology and epistemology for spatial development analysis, but does not expand the specific theories that shed light on the various dimensions and questions of regional and local development. To this end, we should return to the survey of theories in sections 2 and 3 which offer specific intelligence on each of these dimensions: e.g. Myrdal on economic and political factors and mechanisms of centre-periphery relations, Hirschman on the significance of political processes in regional development, Lipietz on the links between the reproduction of economic structure and the State apparatus, Markusen on the role of social and political movements in the regionalization process; and many others. Looking at these theories within this newly defined triangular field of 'social relations - networks of agents - cultural dynamics' may offer a wind of change yet one redolent of the prickling dust of historical manuscripts that are badly needed today but have rested for too long on library shelves - in addressing regional development and policy. 


\title{
5. References
}

\author{
AMIN A. (1999) An institutionalist perspective on Regional Economic Development, \\ International Journal of Urban and Regional Research, 23(2), 365-378.
}

\begin{abstract}
AYDALOT Ph. (1986) Milieux innovateurs en Europe. (Innovative 'Milieux' in Europe). GREMI, Paris.

BECATTINI G. (1987) Mercato e forze locali: il distretto industriale.Il Mulino, Bologna.
\end{abstract}

BLUNT, A. and WILLS, J. (2000) Dissident Geographies: An introduction to radical ideas and practice, Pearson Education, Harlow.

\author{
COE, N.M., HESS, M., YEUNG, H.W.C., DICKEN, P., and HENDERSON, J. (2004) \\ 'Globalizing' regional development: a global production networks perspective, \\ Transactions of the Institute of British Geographers 29(4), 468-484
}

\begin{abstract}
COOKE, Ph. (1996) Reinventing the region: firms, clusters and networks in economic development, in DANIELS, P. and LEVER, W. (Eds) The global economy in transition. Longman, Harlow.
\end{abstract}


COOKE, Ph. and Morgan, K. (1998) The Associative Region, Oxford University Press, Oxford.

COX, K.R. (2004) Globalization and the politics of local and regional development: the question of convergence, Transactions of the Institute of British Geographers 29(2), 179194

DEAN, M. (1999) Governmentality: Power and Rule in Modern Society, Sage, London.

DICKEN, P. (1994) The Roepke Lecture in Economic Geography. Global-Local

Tensions: Firms and States in the Global Space-Economy. Economic Geography 70(2), 101-128.

DUNFORD, M. (1988) Capital, the State and Regional Development, London, Pion

DUNFORD, M and GRECO, L. (2006) After the Three Italies, Blackwell, Oxford.

EDQUIST, Ch. (Ed) (1997), Systems of Innovation: Technologies, Institutions and Organizations. Pinter, London

FAIRCLOUGH, N. (1992) Discourse and Social Change. Polity, Cambridge. 
FUJITA, M. KRUGMAN, P. and VENABLES, A.J. (1999) Spatial Economy. Cities, regions, and international trade. MIT Press, Cambridge MA.

GIBSON-GRAHAM, J.K. (1996) The End of Capitalism. Blackwell, Oxford.

GONZALEZ, S. (2005) The politics of the economic crisis in the Basque Country and Spain during the 1980s. Space and Polity 2005, 9(2), 93-112.

GONZALEZ, S (2006) Scalar narratives in Bilbao: A cultural politics of scales approach to the study of urban policy. International Journal of Urban and Regional Research. 30(4), 836-857.

HADJIMICHALIS, C. (2006) Non-economic factors in economic geography and in 'new regionalism': A sympathetic critique. International Journal of Urban and Regional Research, 30(3), 690-704.

HADJIMICHALIS, C. and HUDSON, R. (2006) Networks, Regional Development and Democratic Control. International Journal of Urban and Regional Research, 30(4), 858-872.

HAJER, M. (1995) The politics of environmental discourse. Ecological modernization and the policy process, Oxford University Press, Oxford. 
HARVEY, D. (1982) The Limits to Capital, The University of Chicago Press, Chicago.

HASSINK, R. and LAGENDIJK, A. (2001) The dilemmas of interregional institutional learning, Environment and Planning C: Government and Policy, 19(1), 65-84.

HESS, M. (2004) 'Spatial' relationships? Towards a reconceptualization of embeddedness, Progress in Human Geography, 28(2), 165-186

HIRSCHMAN, A. O. (1958) The strategy for economic development, Yale University Press, New Haven CT

HIRSCHMAN, A.O. (1984) The On and Off Connection Between Political and Economic Progress, The American Economic Review, 84(2), 343-348.

HOLLAND S. (1976) Capital versus the Regions, The MacMillan Press, London.

HOSELITZ, B. F. (1960) Theories of Economic Growth, Free Press, New York.

HUDSON, R. (2001) Producing Places. Guilford, New York.

HYMER, S. (1972) The multinational corporation and the law of uneven development, in BHAGWATI, J. (Ed), Economics and the World Order, The Macmillan Press, London. 
JESSOP, B. (1990) Regulation Theories in Retrospect and Prospect, Economy and Society, 19(2), 153-216.

JESSOP, B. (2001) Institutional re(turns) and the strategic relational approach, Environment and Planning A, 33(7), 1213-1235.

JESSOP, B. and SUM, N-L. (2006) Beyond the regulation approach: putting capitalist economies in their place, Edward Elgar, Cheltenham

KEATING, M. (1998) The New Regionalism in Western Europe: territorial restructuring and political change. Edward Elgar, Cheltenham.

LEBORGNE, D. and LIPIETZ, A (1990) Fallacies and Open Issues of Post-Fordism, Couverture Orange , no. 9009, CEPREMAP, Paris

LEFÈBVRE, H. (1974) [2004] The Production of Space. Blackwell, Oxford.

LIPIETZ, A. (1977) Le Capital et son Espace. Maspero, Paris.

LIPIETZ, A. (1980) Le teriaire, arborescence de l'accumulation capitaliste: prolifération et polarisation. Critiques de l'Economie Politique, July-September, 17-69. 
LÖSCH, A. (1938) The nature of economic regions, Southern Economic Journal, 5(1), $71-78$

LOVERING, J. (2001) The Coming Regional Crisis (And How To Avoid It), Regional Studies, 35(4), 349-54.

MACKINNON, D., CUMBERS, A., and CHAPMAN, K. (2002) Learning, innovation and regional development: a critical appraisal of recent debates, Progress in Human Geography 26(3), 293-311

MARTINELLI, F. and MOULAERT, F. (1993) The Location of Advanced Producer Services Firms: Theory and Illustrations. Geographische Zeitschrift, 81(1-2), 1-17.

MARKUSEN A., (1983), Regions and Regionalism, in MOULAERT, F. and WILLSON P. (Eds) Regional Analysis and the New International Division of Labor, Kluwer Nijhoff Publishing, Boston.

MASSEY, D. (1984) Spatial Divisions of Labour. Social structures and the geography of production, Macmillan, London.

M ${ }^{\mathrm{C}}$ GUIRK, P. (2004) State, strategy and scale in the competitive city: a neo-gramscian analysis of the governance of 'global Sydney'. Environment and Planning A, 36(6), 1019-1043. 
MEARDON, S. J. (2001) Modelling Agglomeration and Dispersion in City and Country:

Gunnar Myrdal, François Perroux, and the New Economic Geography', American

Journal of Economics and Sociology, 60(1), 25-57

MOULAERT, F. (1987) An Institutional Revisit of the Storper-Walker Theory of Labor. International Journal of Urban and Regional Research, 11(3), 309-330.

MOULAERT, F. (1996) Rediscovering spatial inequality in Europe. Building blocks for an appropriate "regulationist" framework. Society and Space, 14(2), 155-179

MOULAERT, F. and CABARET, K. (2006) Planning, networks and power relations: Is democratic planning under capitalism possible? Planning Theory, 5(1), 51-70.

MOULAERT, F., MARTINELLI, F., GONZALEZ, S., and SWYNGEDOUW, E. (2007) Social Innovation and Governance in European Cities: Urban development between path dependency and radical innovation, European Urban and Regional Studies, 14(3), 195209.

MOULAERT, F. and MEHMOOD, A. (2008) Analysing regional development: From territorial innovation to path dependent geography, in Davis, J. and Dolfsma, W. (Eds.) The Elgar Companion to Social Economics, Edward Elgar, Cheltenham 
MOULAERT, F. and NUSSBAUMER, J. (2005) The Social Region: Beyond the territorial dynamics of the learning economy, Journal of European Urban and Regional Studies, 12(1), 45-64.

MOULAERT, F. and SEKIA, F. (2003) Territorial Innovation Models: a Critical Survey, Regional Studies, 37(3), 289-302.

MOULAERT, F., SEKIA, F., and BOYABÉ, J.B. (1999) Innovative region, social region? An alternative view of regional innovation, IFRESI Discussion Paper, Lille

MOULAERT, F., SWYNGEDOUW, E. and WILSON, P. (1988) The Geography of Fordist and Post-Fordist Accumulation and Regulation, Papers of the Regional Science Association, 64, 11-23.

MOULAERT, F. and SWYNGEDOUW, E. (1989) 'Survey 15: A regulation approach to the geography of flexible production systems', Environment and Planning D: Society and Space, 7(3), 327-345.

MYRDAL G. (1957) Economic Theory and Underdeveloped Regions, Duckworth, London.

MULLINGS, B. (2005) Women Rule? Globalization and the feminization of managerial and professional workspaces in the Caribbean, Gender, Place and Culture, 12(1), 1-27 
NOVY, A. and B. LEUBOLT (2005) Participatory Budgeting in Porto Alegre: Social Innovation and the Dialectical Relationship of State and Civil Society. Urban Studies, 42(11), 2023-2036.

NUSSBAUMER, J. (2002) 'Le rôle de la culture et des institutions dans les débats sur le développement local: la contribution de l'Ecole Historique Allemande' [The role of culture and institutions in the debates on local development: the contribution of the German Historical School], unpublished PhD thesis, Lille: University of Lille I, Faculty of Social Science.

PECK, J (1996) Work Place. The Social Regulation of Labor Markets, The Guilford Press, New York/London.

PECK, J. and TICKELL, A. (1992) Local modes of social regulation? Regulation theory, Thatcherism and uneven development. Geoforum, 23(3), 347-364.

PERROUX, F. (1955) Note sur la notion de "pôle de croissance", Economie Appliquée 8. Republished and translated in McKEE, D. L., DEAN, R.D. and LEAHY, W.H. (Eds) (1970) Regional Economics, pp. 93-103, The Free Press, New York.

PERROUX, F. (1983) A New Concept of Development: Basic Tenets, Croom Helm, London 
PERROUX, F., (1988) 'The Pole of Development's New Place in a General Theory of Economic Activity', in HIGGINS, B. and SAVOIE, D.J. (Eds) Regional Economic Development: Essays in Honour of François Perroux, pp. 48-76, Unwin Hyman, Boston.

RACO, M. (2003) Governmentality, Subject-Building and the Discourses and Practices of Development in the UK, Transactions of the Institute of British Geographers, 28(1), 75-95.

ROSE, N. and MILLER, P. (1992) Political Power Beyond the State: Problematics of Government, British Journal of Sociology, 43(2), 173-205.

SAYER, A. (1992) Method in Social Science: A Realist Approach, Routledge, London.

SAXENIAN, A. (1994) Regional Advantage. Culture and Competition in Silicon Valley and Route 128. Harvard University Press, Cambridge.

SCHMOLLER, F.G. (1884) Das Merkantilsystem in seiner historischen Bedeutung:

Städtische, territoriale und staatliche Wirtschafts-politik, Jahrbuch für Gesetzgebung, Verwaltung und Volkswirtschaft im Deutschen Reich, VIII 15-61

SCHMOLLER, F.G. (1905) Principes d'Economie Politique, V.Giard et E. Brière, Paris. 
SMART, B. (1986) The Politics of Truth and the Problem of Hegemony, in HOY, D.C. (Ed.) Foucault: A Critical Reader, pp. 157-73, Basil Blackwell, Oxford.

STORPER, M. and SCOTT, A.J. (1988) The Geographical Foundations and Social Regulation of Flexible Production Complexes, in WOLCH, J. and DEAR, M. (Eds) The Power of Geography. pp. 21-40, Allen and Unwin, London.

STORPER, M. and WALKER, R. (1983) The theory of labor and the theory of location. International Journal of Urban and Regional Research 7(1), 1-44.

SUM, N-L. (2002) Globalization and Hong Kong as an Entrepreurial City Strategies: Contested Visions and the Remaking of City Governance in (Post-) Crisis Hong Kong, in LOGAN, J. (Ed.) The New Chinese City: Globalization and Market Reform, pp. 74-91, Blackwell, Oxford.

SUM, N-L. (2005) From the Regulationist Approach to Cultural Political Economy. DEMOLOGOS working paper, [on website: http://demologos.ncl.ac.uk/wp/wp1/disc.php December 2005].

SUM, N-L. (2006) Culture, Discourse, Ideology, and Hegemony, DEMOLOGOS working paper, [on website: http://demologos.ncl.ac.uk/wp/wp2/disc.php August 2006] 
SUM, N-L. and Jessop, B. (2007) Towards a Cultural Political Economy, Edward Elgar, Cheltenham.

SWYNGEDOUW, E. (1997) La Reconstruction de la Choreographie Espace / Temps de la Monnaie Mondiale. Espaces et Sociétés, 88-89, 53-90

SWYNGEDOUW, E. (2005) Governance Innovation and the Citizen: The Janus Face of Governance-beyond-the-State. Urban Studies, 42(11), 1991-2006.

TÖDTLING, F. and TRIPPL, M. (2005) One size fits all? Towards a differentiated regional innovation policy approach. Research Policy, 34, 1203-1219.

VILLEVAL, M.C. (1995) Une théorie économique des institutions? in BOYER, R. and SAILLARD, Y. (Eds) L'Ecole de la Régulation. L'Etat des Savoirs. pp. 479-489, Presses Universitaires de France, Paris.

WILLIAMS, A.M., BALAZ, V., and WALLACE, C. (2004) International Labour Mobility and Uneven Regional Development in Europe: Human Capital, Knowledge and Entrepreneurship, European Urban and Regional Studies, 11(1), 27-46

YEUNG, H. Wai-Chung (2005) Rethinking Relational Economic Geography, Transactions of the Institute British Geographers, 30(1), 37-51 


\section{Table 1 Views of innovation in territorial innovation models}

\begin{tabular}{|c|c|c|c|c|}
\hline $\begin{array}{r}\text { Model } \\
\text { Features of innovation }\end{array}$ & $\begin{array}{l}\text { Milieu innovateur } \\
\text { (Innovative milieu) } \\
\text { (MI) }\end{array}$ & Industrial District (ID) & $\begin{array}{l}\text { Regional Innovation } \\
\text { Systems (RIS) }\end{array}$ & New Industrial Spaces \\
\hline $\begin{array}{l}\text { Core of innovation } \\
\text { dynamics }\end{array}$ & $\begin{array}{l}\text { Capacity of a firm to } \\
\text { innovate through the } \\
\text { relationships with other } \\
\text { agents of the same } \\
\text { milieu }\end{array}$ & $\begin{array}{l}\text { Capacity of actors to } \\
\text { implement innovation } \\
\text { in a system of common } \\
\text { values }\end{array}$ & $\begin{array}{l}\text { Innovation as an } \\
\text { interactive, cumulative } \\
\text { and specific process of } \\
\text { research and } \\
\text { development (path } \\
\text { dependency). }\end{array}$ & $\begin{array}{l}\text { A result of } \mathrm{R} \& \mathrm{D} \text { and } \\
\text { its implementation; } \\
\text { application of new } \\
\text { production methods } \\
\text { (JIT, etc.) }\end{array}$ \\
\hline Role of institutions & $\begin{array}{l}\text { Very important role of } \\
\text { institutions in the } \\
\text { research process } \\
\text { (university, firms, } \\
\text { public agencies, etc.) }\end{array}$ & $\begin{array}{l}\text { Institutions are } \\
\text { "agents" and enabling } \\
\text { social regulation, } \\
\text { fostering innovation } \\
\text { and development }\end{array}$ & $\begin{array}{l}\text { As in the NIS, the } \\
\text { definitions vary } \\
\text { according to authors. } \\
\text { But they all agree that } \\
\text { the institutions lead to } \\
\text { a regulation of } \\
\text { behaviour, both inside } \\
\text { and outside } \\
\text { organisations }\end{array}$ & $\begin{array}{l}\text { Social regulation for } \\
\text { the co-ordination of } \\
\text { inter-firm transactions } \\
\text { and the dynamics of } \\
\text { entrepreneurial activity }\end{array}$ \\
\hline Regional development & $\begin{array}{l}\text { Territorial view based } \\
\text { on "milieux } \\
\text { innovateurs" and on } \\
\text { agent's capacity of } \\
\text { innovating in a co- } \\
\text { operative atmosphere }\end{array}$ & $\begin{array}{l}\text { Territorial view based } \\
\text { on spatial solidarity } \\
\text { and flexibility of } \\
\text { districts. This } \\
\text { flexibility is an } \\
\text { element of this } \\
\text { innovation }\end{array}$ & $\begin{array}{l}\text { View of the region as a } \\
\text { system of "learning by } \\
\text { interacting/ and by } \\
\text { steering regulation", }\end{array}$ & $\begin{array}{l}\text { Interaction between } \\
\text { social regulation and } \\
\text { agglomerated } \\
\text { production systems }\end{array}$ \\
\hline Culture & $\begin{array}{l}\text { Culture of trust and } \\
\text { reciprocity links }\end{array}$ & $\begin{array}{l}\text { Sharing values among } \\
\text { ID agents - Trust and } \\
\text { reciprocity }\end{array}$ & $\begin{array}{l}\text { The source of "learning } \\
\text { by interacting" }\end{array}$ & $\begin{array}{l}\text { Culture of networking } \\
\text { and social interaction }\end{array}$ \\
\hline $\begin{array}{l}\text { Types of relations } \\
\text { among agents }\end{array}$ & $\begin{array}{l}\text { The role of the support } \\
\text { space: strategic } \\
\text { relations between the } \\
\text { firm, its partners, } \\
\text { suppliers and clients }\end{array}$ & $\begin{array}{l}\text { The network is a social } \\
\text { regulation mode and a } \\
\text { source of discipline. It } \\
\text { enables a coexistence } \\
\text { of both co-operation } \\
\text { and competition }\end{array}$ & $\begin{array}{l}\text { The network is an } \\
\text { organisational mode of } \\
\text { "interactive learning" }\end{array}$ & Inter-firm transactions \\
\hline $\begin{array}{l}\text { Types of relations } \\
\text { with the environment }\end{array}$ & $\begin{array}{l}\text { Capacity of agents in } \\
\text { modifying their } \\
\text { behaviour according to } \\
\text { the changes in their } \\
\text { environment. Very } \\
\text { 'rich' relations: third } \\
\text { dimension of support } \\
\text { space }\end{array}$ & $\begin{array}{l}\text { The relationships with } \\
\text { the environment } \\
\text { impose some } \\
\text { constraints and new } \\
\text { ideas. Must be able to } \\
\text { react to changes in the } \\
\text { environment. 'Rich' } \\
\text { relations. Limited } \\
\text { spatial view of } \\
\text { environment }\end{array}$ & $\begin{array}{l}\text { Balance between inside } \\
\text { specific relations and } \\
\text { environment } \\
\text { constraints. 'Rich' } \\
\text { relations }\end{array}$ & $\begin{array}{l}\text { The dynamics of } \\
\text { community formation } \\
\text { and social reproduction }\end{array}$ \\
\hline
\end{tabular}




\section{Figure 1 A meta-theoretical synthesis for regional development analysis: Regulation, Network and CPE approaches}

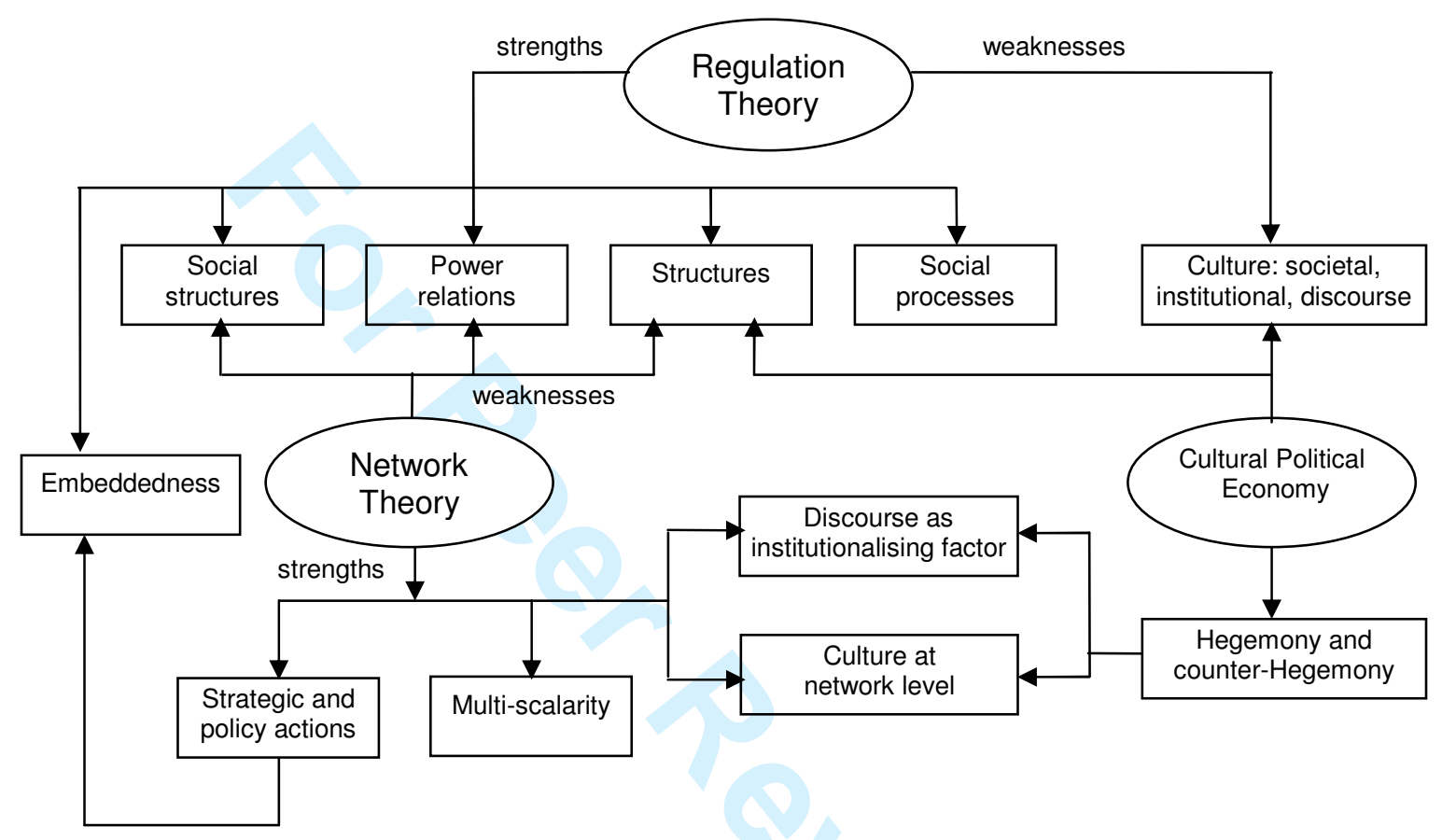




\section{Endnotes}

\footnotetext{
${ }^{\mathrm{i}}$ This paper does deal with regional development, not regional growth theories. Although there exist affinities between both analytical traditions, we have no space to deal with both and we prefer to address the more 'quality features' oriented development theories. As a consequence we will for example not present the debate on/between New Economic Geography and regional endogenous growth models (see e.g. FUJITA, KRUGMAN and VENABLES, 1999).

${ }^{\text {ii }}$ Andrew Sayer has summarised the realist scientific-philosophical approach as having the following features: (a) the world exists independently of our knowledge of it; (b) our knowledge of the world is preinformed but also imperfect; (c) "Knowledge develops neither wholly continuously, as the steady accumulation of facts within a stable conceptual framework, nor wholly discontinuously, through simultaneous and universal changes in concepts." (p. 5) (d) objects (natural or social) have particular causal powers or ways of acting and particular susceptibilities; (e) "The world is differentiated and stratified, consisting not only of events, but objects, including structures, which have powers and liabilities capable of generating events." [...] (f) "Social phenomena such as actions, texts and institutions are concept dependent" (p. 6) [...] (g) "Science or the production of any other kind of knowledge is a social practice. For better or worse (not just worse) the conditions and social relations of the production of knowledge influence its content. Knowledge is also largely - though not exclusively - linguistic, and the nature of language and the way we communicate are not incidental to what is known as communicated. Awareness of these relationships is vital in evaluating knowledge."; (h) "Social science must be critical of its object"” $[\ldots]($ p. 6)

iii Contemporary debates on New Regionalism take different directions, especially following criticisms of the neglect of articulation among spatial scales and their consequences for economic policy. We have reserved the term 'New Regionalism' for the original spatially disarticulated models, preferring to refer to the spatially articulated models as 'Beyond New Regionalism'. - see section 4.1. Neither do we address the political science literature on New Regionalism (see e.g. KEATING, 1998). Although we believe that Markusen's Regionalism concept (section 3.3.2) could play a significant role there.
} 
${ }^{\text {iv }}$ This section has been reproduced and extended from Moulaert and Nussbaumer (2005). Copyright granted by SAGE Publications.

${ }^{\mathrm{v}}$ For details see Moulaert, Sekia and Boyabé (1999).

${ }^{\mathrm{vi}}$ For more details see Moulaert, Sekia and Boyabé, op. Cit. See also MacKinnon, Cumbers and Chapman (2002) who among other critical observations point out how the learning region model underemphasises the articulation among spatial scales in learning dynamics.

vii The GHS also played a significant role in the genesis of location theory; this is not developed here. See Nussbaumer (2002).

viii We should also keep in mind that the theory of stages of economic growth also had an influence on Lösch's theory of system of regions (LÖSCH 1938).

${ }^{\text {ix }}$ See also Williams et al. (2004) on the relationship between migration flows and uneven development in contemporary Europe.

${ }^{\mathrm{x}}$ We selected these two authors because their focus is regional compared to other authors from the1970s working in radical political geography and their analysis fits best the trajectory leading to the structuralrealist synthesis in regional development analysis, which we pursue. If we had to further extend this methodological exercise we would certainly make made use of Dunford (1988) and Harvey (1982) 